Article

\title{
Effectiveness of Online Digital Media Advertising as A Strategic Tool for Building Brand Sustainability: Evidence from FMCGs and Services Sectors of Pakistan
}

\author{
Rizwan Raheem Ahmed ${ }^{1}$, Dalia Streimikiene ${ }^{2, * \mathbb{D}}$, Gerhard Berchtold ${ }^{3}$, Jolita Vveinhardt ${ }^{4}$, \\ Zahid Ali Channar ${ }^{5}$ and Riaz Hussain Soomro ${ }^{6}$ \\ 1 Faculty of Management Sciences, Indus University, Block-17, Gulshan, Karachi 75300, Pakistan; \\ rizwanraheemahmed@gmail.com \\ 2 Lithuanian Sports University, Institute of Sport Science and Innovations, Sporto Str. 6, \\ 44221 Kaunas, Lithuania \\ 3 Department of Business Studies (International program), University of Azteca and University of Nicaragua, \\ 6020 Innsbruck, Austria; gerhard@businessschooldirect.info \\ 4 Faculty of Economics and Management, Vytautas Magnus University, Daukanto Str. 28, \\ 44248 Kaunas, Lithuania; Jolita.Vveinhardt@gmail.com \\ 5 Department of Business Administration, Sindh Madressatul Islam University, Karachi 74000, Pakistan; \\ drzahidalic@gmail.com \\ 6 Institute of Health Management, Dow University of Health Sciences, Mission Road, Karachi 74200, Pakistan; \\ riaz.soomro@duhs.edu.pk \\ * Correspondence: dalia@mail.lei.lt; Tel.: +370-6140-3424
}

Received: 6 May 2019; Accepted: 19 June 2019; Published: 21 June 2019

check for updates

\begin{abstract}
The purpose of the undertaken study is to examine the effectiveness of online digital media advertising as a strategic tool for building brand sustainability. For this purpose, we investigate the impact of different channels of online media, such as email marketing, mobile phone marketing, search engine optimization and companies' websites, and social media marketing for the effectiveness of online digital media advertising. Moreover, the researchers have introduced eight mediating variables and six moderating variables to examine the impact between exogenous variables and online digital media advertising (endogenous). The researchers have taken 910 responses through a modified questionnaire and employed quantitative research methods, such as the structural equation modeling, exploratory factor and confirmatory factor analyses, and Hayes process approach for examining the mediation and moderation amongst the variables. The results of direct impact have demonstrated that all of the channels of digital media advertising have a positive and significant influence on the effectiveness of online digital media that creates brand sustainability for fast moving consumer goods (FMCG) and services sectors of Pakistan. The outcomes of hypotheses pertaining to the mediating and moderating effects of different variables have shown the significant influence between exogenous variables and endogenous variable. The results of the undertaken study are beneficial for the existing literature that provides the basic foil for future research studies. Moreover, the results have significant industrial implications for the marketers and digital media managers that they can devise effective media and marketing strategies to maintain optimum market share and competitive advantages.
\end{abstract}

Keywords: brand sustainability; online digital media advertising; email marketing; mobile phone marketing; SEO and companies' websites; social media marketing 


\section{Introduction}

Traditional media communication medium was considered to be very important a few years ago, but from last few years the digital media is prospering considerably and it has become a very important mode of communication in marketing and advertising for building brand sustainability. Digital marketers interact and communicate effectively and inexpensively to the customers by using the mechanism of digital media channels. Due the rise and popularity of this new media, the marketers are providing information and advertising campaigns to their consumers by utilizing digital innovation for last decade and it has now become very easy to build brand sustainability through digital media advertising [1]. New media has empowered marketers to promote and distribute their offers and new products to consumers. More interestingly, they no longer require their computers-rather high-tech mobile phones, portable computers, and through the portal, the real-time exchange of information can be transmitted anywhere and at any time to their customers, and, for this reason, consumer's behavior has become an essential element [2]. With the expansion of new channels of digital media the traditional print and electronic media, like magazines, newspapers, TV, hoardings, and billboards facing real threats and major crises [3]. The millions of customers use the companies' websites, YouTube, online portals for watching different brands, and it was a real challenge for marketers to build their brands [4]. The introduction of new interactive media was also crafted new business opportunities and new business and advertising horizons for marketers. User-generated content in new interactive media, for instance, Twitter, YouTube, and Facebook, the customers showed their enthusiasm by sharing and talking about their favorite brands. According to Mathwick et al. [5], these media also reduce the phenomenal cost of advertising and enhancing the effect of many folds. Business organizations reach to customers and interact with them, and their interactions, through browsing or purchasing through the use of this new media and companies can trigger or stimulate their purchase behaviors through different practices and measure multiple modes. These options are usually valued for marketing, but individual users have particular relevance to developing individual marketing activities on the employees, customer relationship management. New media using the opportunities, which are provided by the new media users, are attracted to a full understanding of how and why they affect customers' attitude and behavior in order to build brand sustainability. Novel strategy and the pre-amative marketing approach and new media properties are in line with their impact on consumers, which must be developed $[5,6]$. New media is a broad concept that focuses on emerging media trends that prevent previous forms, newspapers, books, or other forms of writing. Tasks that require manual skills can now be more efficiently carried out and more complex, while taking into account less time and energy. Most people who have Internet access are familiar with the concept of new media, which includes Facebook and Twitter, and video blog sites, such as YouTube. The new media has greatly changed with the invention of microprocessors, such as Handhelds, using interactive applications on smartphones. As the new media is constantly improving to connect to as many different platforms and people as possible, one of the key features is interactivity. The real-time conversion has made this conversion process easy. "Cyber-chat" has become instantaneous for the general public, especially for young people, in the 20th century. Blogs are a form of new media that expanded the concepts of our interactivity level that is created by the new media. The ability of anyone to publish a text, a photo, or a video was seen as a gain in communication, and, in particular, the number of e-journalists. Today, there is more personalization, individualized results for each user, which are customized for each request [7-10].

The undertaken study is an effort to examine the importance and effectiveness of online digital media advertising for building brand sustainability. The online digital media is a real-time medium of communication that uses as a strategic tool for building brands through marketing and advertising campaigns. Companies are now more tilted towards the different channels of digital media. The interactive online digital media is an effective channel for interacting with the consumers at real-time, and get the instantaneous feedback regarding the products and services. The companies are using this media due to the cost effectiveness and reach when compared to the conventional media. 
Another important reason for using the interactive online digital media is the customer relationship is that the marketers have direct interaction with the consumers due to the variety of online channels, thus companies have better relationship and communication with their customers through this media [8,9]. The digital online media is not only cost effective, but is also user-friendly and it provides numerous digital channels to connect with the consumers. The term "Globalization" is fit for the online digital media, thus, with the help of digital online media, the companies launch their products and services globally with minimal cost. The new digital media capture the audiences from all over the World, in reality; the new interactive digital media has translated the true essence globalization. The customer can use the interactive digital media to provide their suggestions and comments regarding the products and services, and to also discuss the good and bad characteristics of the company's products. Therefore, companies can obtain immediate feedback regarding their products and can alter their strategies timely for the long-term sustainability of their brands $[10,11]$. The use of this new media has become imperative and important for Pakistani companies; marketers also understand the importance of this media as a strategic tool for building brand sustainability. Globally, many researches have been carried out, but all of these researches are either generic or conducted in the international perspective by keeping in view of their own local culture and business atmosphere. Hence, there is an utmost need to carry out a research study in Pakistani perspective [12,13]. However, few research studies have been carried out in Pakistan but the scope of these studies were very narrowed and limited. Moreover, the practical implementation and implications are missing, therefore, there is a strong need to conduct detailed and thorough research, which addresses all of the aspects of digital media. In this research, we have taken ten different sectors of the economy and also incorporated the survey of consumers and professionals.

\subsection{The Objective of the Research}

The objective of the research is to evaluate the creativity and effectiveness of digital media for building brands sustainability for the Pakistani companies and to also assess its utility and effectiveness from the consumers', professionals', and marketers' perspective. The results of the study help to the current and potential online buyers for selecting the medium for their purchase decision and, at the same time, the outcomes of the study are also helpful to the marketers of services and manufacturing sectors to formulate their online media communication campaigns in order to attract maximum consumers for their products and services. The marketers can examine the effectiveness of interactive digital communication tools from the analysis of the results of this study, and they can incorporate digital media communication tools in their IMC plans. The advertising agencies can obtain a better understanding of the different channels of digital media communication and they can incorporate in their campaigns to facilitate their organizational customers in a better way. A common consumer can assess the effectiveness of different online digital media and choose the best one for their online purchase decision. The government and different regulatory bodies can formulate different rules and regulations to protect the consumer who is using this online medium.

\subsection{The Novelty and Significance of this Research Study}

The significance of this research is many folds, because this is the first kind of the study that examines the building brands sustainability for the Pakistani companies. In the undertaken study, we employed an important digital media tools and evaluated the impact of digital media channels on the effectiveness of advertising for different sectors of Pakistan [12]. Eight mediating and six moderating variables have also been incorporated and evaluated the impact in an association of digital media tools and their influence on advertising for service and manufacturing industry of Pakistan. Thus, this research also investigated consumers' attitude, brand loyalty, previous purchase experience, the design of an advertisement, quality content of the advertisement, and the duration of advertisement as the mediating variables [11,12]. This research has also taken care of technology constituents as moderating variables, and it incorporated different dimensions of information and 
telecommunication technologies, such as smartphone, generation technologies (1G-5G), speed of processors, and fiber optics technology, and identified the role of these moderating variable for building brands sustainability, and the overall impact on the effectiveness of advertising for Pakistani services and manufacturing industry. The undertaken study is an exclusive that provides guidelines to the marketers and advertisers as to how and which element is important while they are making their marketing communication messages on digital media channels. Finally, this research also provides a basic foil to the researchers and scholars for their research studies.

\section{Review of Previous Literature}

Famous scholarly literature and practitioners discovered the term interactivity in the early 1990s [13]. Numerous researches have been conducted by various scholars on how people interact while using different media channels, how consumers and individuals interface with technical tools, such as computers and telecommunication tools, and what is the nature of the content of interactivity. These days, the concept of interactivity is considered as central and the main characteristics of media. However, researchers cannot conclude and generalize that all new digital media tools are interactive, and it is very crucial to comprehend which characteristics make these media channels to interactive [14]. Most importantly, people in various contexts and situations perceive the concept of interactivity differently. If the practitioners have a clear understanding of what interactivity is then it can lead to such environments, which can facilitate interaction among them. It has been understood that all those consumers who can utilize these new digital channels, they can more efficiently use it interactivity if they have a clear understanding of it [15]. Furthermore, from the scholar's perspective, it is very vital to understand interactivity in order to propose and develop theories regarding new media.

\subsection{New Online Digital Media}

Most of the researchers have tried to create a link between new and old media. Many of the metaphors were investigated that how emailing, roundtable, telegraph, and the bonfire are different from each other [16]. The most important thing is how both media are different from each other. The main differentiating factor is that basis of new media is a digital rather than physical fragment [17]. Consumers have more control and choice over new media rather than old media [18]. There are major hallmarks of new media, which includes demassification, interactivity, and synchronicity. Other than that, new media create a scale between mass communication methods and categories of interpersonal communication $[19,20]$. The art of mass communication is advanced and enhanced due to the advent of technological advancement excluding the innovation of telephone. These new technologies are shifting toward interpersonal communication [21]. There were numerous ways that were identified in which new technologies facilitate interpersonal communication [22]. Currently, the focus of research studies is shifted to identify the features and attributes of interactivity $[10,23]$. Few of the researchers have attributed specific features of interactivity with focused strategies, such as virtual stores, mass customization, and importance of learning in collaborative form [24,25].

\subsection{Perceived Interactivity}

Researchers who were trying to identify the attributes of interactivity got criticized from other groups of researchers. The other group suggested that interactivity is a phenomenon that can be seen in the eyes of the beholder. Basically, it is how a consumer perceives it [26-29]. The concept of interactivity can be conceptualized by considering qualitative experiences of consumers [26-28]. According to Chitra and Sasikala [27], it is very crucial to understand how consumer considers interactivity in order to find out how new technologies and the form of media is influencing them in their personal lives. Individual perception must be considered as a focal point to understand the concept of interactivity and new online media $[29,30]$. It is found that, how consumer perceive the concept of interactivity is directly related to how they use Web sites and how they interact with these websites [31-34]. Their perception leads to their interaction with technologies, such as computers [35,36]. According to Lee [30], it is very 
important to understand how consumers perceive and uses that particular form of media, rather than investigating what is the level of interactivity with respect to technical features of new media. There are two wide-ranging kinds of interactivity, which are how it interacts with individuals and what kind of interaction it has with technology [37]. Two interactivities between machine and person interactivity were also identified. Other than that, how humans interact with each other and how human interaction with media was identified [38]. It is identified that there are several levels of interactivity, such as consumer-to-consumer, user-to-computer, and consumer-to-document, etc. [39]. Other researchers have also identified these three-dimensional concepts of interactivity $[40,41]$. Other dimensions of interactivity can be seen as artificial intelligence and interaction in program dominant [40]. According to Mahler and Rogers [37], the main aim or focal point of interactive telecommunication innovation is to associate those individuals who have adopted technology or either link that adopter to others who have adapted to similar innovation.

\subsection{Interacting with New Online Digital Media}

The new form of collaborative mass media has been noted. In the context of this concept, the audience or consumers are the main cause of media contents that are available to its creators. The definitions of mass media have been developed, which focus on diversion from one-to-many and many-to-many communication forms [42,43]. Few of the scholars argued that the concept of interaction with creators of content is not merely based on its creators, but rather the main focus is on audience, which is considered as an active receiver of information, not just a passive receiver of information in new literature [44-48]. It is suggested that there must be an association between interactive content and actions of individuals. According to Rafaeli and LaRose [45], a concept of interactivity must refer to such situations where prompt and real feedback is established from the receivers of a different communication channel and various sources are used to regularly update and enhance the message, which is received and then delivered to a particular receiver.

\subsection{Online Digital Media Characteristics}

A difficult problem can be seen in the analysis of the impacts and effectiveness of interactive media is that the digitalization or emergence of the Internet is basically a new idea or concept that has recently emerged and most of marketers and customers have just adopt it for usage. So today's usage of interactive media is inclined to mix up with the impact of new technology implementation along with long terms impact of interactivity [49]. According to Leonard-Barton [47], the new digital technology implementation is not according to the current method of marketer and consumer communication. With the emergence of new methods or technologies, the hurdles come in the way of implementation and usage of new media; it is due to the fact that new media has certain unique features or systems as sophistication level, restrictiveness, and completeness [50,51]. As the interactivity is dependent on the implementation of media, it is significant to separate the elements of interactive media implementation and usage from the major impact of interactive media once implemented. The implementation of new media has just altered the interaction context. Accordingly, new context of media is emerged by the broadcast media comparative to print, and such context emerged for the time being i.e., radio and television were one time technologically addressed, which render make them enabled to get together in a family $[15,18,52]$.

\section{Conceptual Framework and Hypotheses Formulation}

\subsection{Digital Media Communication Channels}

The new online digital media advertising has provided the new directions to the customary advertising design through giving the basic place to the clients to share the thoughts. It has improved the skylines of correspondence more than the customary. According to Chitra and Sasikala [27] and Çïmecï and Ercan [49], digital advertising gives the workplace to the advertisers and purchasers in 
light of the time and area for speedier reaction. Digital advertisers utilize intuitive and advanced elements for giving data and arranging the clients in view of their necessities, so, along these lines, it is a magnificent and the best media diverts with a specific end goal to make brand mindfulness that helps for building brand sustainability $[53,54]$.

\subsection{Email Marketing Tool and Online Digital Media Advertising}

In the view of McCloskey [50], it has been found that email marketing seems to be a significant part of online marketing tools, where it is the direct way of enabling the communication between customer and seller. The relationship among customer and seller in online marketing or email marketing is just not same as in tradition; for that, the marketers need to construct a way of communication that is liberal in conveying the message with attractive and related content. However, in the views of Moustakas et al. [32], it has been identified that a common online survey showed that most of the executive level online user understands the significance of email marketing. However, the promotional messages are still at the low set up, where a customer does not bother to open the email sometimes. Email marketing has its own advantages, in which one of the most appreciable components is that it helps in promoting green marketing, as there is no paperwork required, so it saves a lot of papers. Statistics show that global email users have increased from 1.2 billion to 4.4 billion. Thus, email advertising has become a highly effective means of conveying a message for building brand sustainability $[55,56]$. The most common use of email advertising is for B2B businesses, and the reason behind this strategy is that it saves printing cost, is highly interactive, and is has an enormous number of users. It helps in creating brand awareness and improving and strengthening marker relations and helps the business in successfully launching its product [57,58]. In improving changes, there is one more type of email marketing emerging that is called "permission-based marketing" [59,60]. Email marketing is used, as there are a number of advantages attached to it, some of them are as: it has a noticeably higher response rates, there is an enormous number of customer available, surprisingly cost-effective medium, a remarkable return on investment when compared to any other mediums, it impacts customers more effectively, is time-saving, creates an effective brand image, and is sustainable [61,62]. On the basis of the above-mentioned we analyzed and designed the following hypothesis:

Hypothesis 1 (H1). Email marketing tool has a positive and significant influence on building brand sustainability, and substantiated the effectiveness of digital media advertising.

\subsection{Mobile Phone Marketing Tools and Online Digital Media Advertising}

The progression in media transmission innovation gives the new and compelling road of special chances to the advertisers to promote their brands and their current and potential clients for building brand sustainability [61-63]. According to Al-Meshal and Almotairi [48], Çizmeci and Ercan [49], Muk [60], Kolla [61], and Barwise and Strong [62], an enormous increment in the mobile phones overall unveiled another medium of advertising for organizations to connect their clients viably. The most broadly utilized mobile phone marketing is the SMS (short message benefit) content advertising, and advertisers use the SMS messaging as a productive tool as compared with the traditional advertising tools [64-68]. According to Bamoriya et al. [63], the SMS advertising channel is more viable and practical when contrasted with the conventional media. The past writing exhibited that SMS publicizing is being broadly utilized in light of its remarkable qualities, simple to target particular pool of clients, and on-going intuitive elements [65-67]. Organizations utilize this medium for both push and pulls techniques, each kind of altered messages can be produced, and the SMS channel could be used without time bar, which makes this medium profoundly viable to make mark mindfulness, and brand faithfulness for their brands [68-70]. The SMS advertising could be utilized for the assorted gathering of clients with bringing down the cost than the conventional media, and the most imperative explanation behind utilizing this medium is a result of high perusing apportion, it is assessed that around $99 \%$ of clients read their SMS [71-76]. The examination of advertising messages highly influences the 
relevance of mobile advertising that helps for building brand sustainability $[77,78]$. Thus, we have formulated the following hypothesis on the basis of previous literature:

Hypothesis 2 (H2). Mobile phone marketing tool has a positive and significant influence on building brand sustainability, and substantiated the effectiveness of digital media advertising.

\subsection{Search Engines Optimization and Companies' Websites and Online Digital Media Advertising}

According to Reyes-Menendez [74] and Breuer et al. [76], the 1.3 billion consumptions are made by heavy internet users who are online buyers of Europe, and these purchases happened every six months, making an average of $€ 747,00$. The consumers use the search engines to show their buying needs and wants, which leads to the purchase of products and services $[79,80]$. Search engines have become very important for generating new leads and bringing new customers [81-83], this is the reason that search engines are taken as the most effective online communication network that helps for building brand sustainability [83-85]. The definition of the SEO, according to the Web design library, is that it is used to assure that a link appears on the top of the page when one searches and types a specific keyword. The aim of the SEO is to increase the number of web visitors and make the website rank very high with the use of correct keyword and by explaining the website content. The task of SEO includes search algorithm and searches of online customers. According to Ahmed et al. [80] and Vakratsas and Ambler [86], when online users search for data with the help of search engines, the opportunities for marketers arise. Count of visitors, stays, again visits, and rise of repeat visits, buying of rejection rate such as 1) Site quality in light of appraisals and honors; consumer loyalty with the site, physical engaging quality, 2) Pages of data given, hit rates, site hits, and stickiness, 3) Cost per click, cost per arrange, cost per client obtained. Paid and natural web search tool rankings, 4) Perceivability: web index rankings and page areas with respect to key contenders, 5) Navigate rates and number of webpage visits from paid and natural pursuit promoting, and 6) Number of changes: qualified leads, beginning buys, and so forth $[87,88]$. Thus, we have formulated the following hypothesis on the basis of previous literature:

Hypothesis 3 (H3). Search Engines optimization and companies' websites have a positive and significant influence on building brand sustainability, and have substantiated the effectiveness of digital media advertising.

\subsection{Social Media Networks and Online Digital Media Advertising}

The social media is a distinctive hallmark to engross customers online in real-time networking across the communities that establish customers' relationship, which enables marketers to create brand awareness and build brand sustainability [89,90]. According to Mangold and Faulds [85], Laroche et al. [87], and Blair [88], the social media offers opportunities of networking between the organization and customers, which provide brand awareness, brand reach, customers' transaction, referrals, brand equity, company's influence, and brand sustainability. According to Çizmeci and Ercan [49] and Laroche et al. [87], the social media has many advantages, like influenced customer behavior by providing information, post-purchase satisfaction, and the Internet usage pattern. Social media has many advantages as compared to other online media; it allows for creating the customized content, exchange of user-generated content, direct connection with the customers, customer relationship, and to translate these advantages into customer building and brand awareness and purchase intentions at minimal expenditure [91-96]. According to Kim et al. [92] and Popp and Woratschek [93], the social media also used the stimulus of customer perceptions and behaviors, therefore, the companies use this media as a strategic tool for developing their strategies in order to increase corporate image, brand loyalty, brand awareness, brand equity, and brand sustainability. Hence, we have formulated the following hypothesis on the basis of previous literature and discussions: 
Hypothesis 4 (H4). Social media marketing tool has a positive and significant influence on building brand sustainability and substantiated the effectiveness of digital media advertising.

\subsection{Mediating Variables and Hypotheses Formulation}

\subsubsection{Characteristics of Advertisement and ONLINE Digital Media Advertising}

Advertisement characteristics, including the design of an advertisement, the quality content of the advertisement, and the duration of advertisement, played a vital role as mediating variables for the attraction and retaining the consumers on real-time media channels [97]. Thus, marketers and advertisers consider these variables as a major influence on online digital advertising for building brand sustainability [98]. As the new interactive media has grown the consumers' needs more moving objects and animation to pay more attention to a particular advertisement [99]. The characteristics played a vital role in the overall attraction of consumers, which offer a competitive advantage to the organization and lead to higher revenues. The customers are interested in the long-lasting outcomes of online advertisement that also attract the consumers by providing rich quality material on the ads. Thus, companies should take care of the contents of the online ads while making their online digital media advertising for building brand sustainability $[49,100]$. If the ads display for a longer period of time then it carries more customer attention and chances of retention. This carryover effect may differ across different digital media; for instance, the email has greater carryover effect when compared to the other digital online medium [101-103]. Thus, keeping in the view of these characteristics of the online advertisement and previous literature, the researchers have developed the following hypotheses:

Hypothesis 5A (H5A). The characteristics of the online ad mediates email marketing tool and the effectiveness of digital media advertising for building brand sustainability.

Hypothesis 5B (H5B). The characteristics of the online ad mediates mobile phone marketing tools and the effectiveness of digital media advertising for building brand sustainability.

Hypothesis 5C (H5C). The characteristics of the online ad mediates search engines optimization and companies' websites marketing channels and the effectiveness of digital media advertising for building brand sustainability.

Hypothesis 5D (H5D). The characteristics of the online ad mediates social media marketing channels and the effectiveness of digital media advertising for building brand sustainability.

\subsubsection{Design of Advertisement and Online Digital Media Advertising}

The elements of an advertisement's design create more attention for sticking on the advertisement for a longer period of time. Consumers always give more importance for two aspects of the online advertisement, such as the security and the user interface of the design. According to Bevan [96], the websites of advertisement should be user-friendly and user-centered, because the E-business systems are referred as customer-facing systems and the significance of human-computer communication is high for the design of web-application. According to Vakratsas and Ambler [86] and Noyes and Baber [97], consumers' only care about their interests and benefits; therefore, the organization should design an ad while taking the consideration of consumers. The design of the ad is played a vital role to gain the attention, which ultimately enhances the organizations' competitive advantage and revenue. The design of ad comprises on: 1) Appeal that includes sex, humor, style, a slice of life, fantasy etc. 2) Text includes attributes such as font, size, color of font etc. 3) Color includes black and white or colorful material [102-104]. The elements of rich-media includes video, music, sound, takeovers, and floating images, and many more. Moreover, the size of ads, color, location, animation, and interactivity influence consumers independently, and consequently, the effectiveness of online ads enhances many folds to engage consumers for a longer period of time that is also helpful 
for building brand sustainability [105]. Therefore, on the above discussions and based on previous literature, the researchers have formulated the following hypotheses:

Hypothesis 6A (H6A). Design of advertisement mediates email marketing tool and effectiveness of digital media advertising for building brand sustainability.

Hypothesis 6B (H6B). Design of advertisement mediates mobile phone marketing tools and effectiveness of digital media advertising for building brand sustainability.

Hypothesis 6C (H6C). Design of advertisement mediates search engines optimization and companies' websites marketing channels and the effectiveness of digital media advertising for building brand sustainability.

Hypothesis 6D (H6D). Design of advertisement mediates social media marketing channels and the effectiveness of digital media advertising for building brand sustainability.

\subsubsection{Duration of Advertisement and Online Digital Media Advertising}

According to Gallagher et al. [104], the consumer has complete and direct control on the online ads to when, where, and how they like to watch and react to these ads; thus, the duration of ads plays a vital role in the effectiveness of online digital media advertising for building brand sustainability $[105,106]$. The format and physical presentation of an ad are also structural components that enhance the duration of the ad to the online consumer [107,108]. Similarly, Danaher and Mullarkey [82] have demonstrated that the effectiveness of online ads depends on the viewing duration of the advertisement webpage. The importance of animation, duration, and location of the web banner ad have distinct importance for the attraction and attention of consumer [109-111]. According to Oliver [107], and Kapferer [110], the duration and location have more prominent role in the effectiveness of banner ad, they further argued that the top on the webpage is the prime location for an online ad with longer duration, which alludes more to the consumers to the stock on the ad. The reappearance experience is one of the most crucial elements in online advertising, as the greatest number of consumers can have exposure to view the ads more than once [112]. This is an important finding that, if the repeated exposure of advertisement does not take place, then there would be chances of a diminishing effect on return on investment, because single exposure of online ads cannot add any value to the consumer. Thus, several research studies recommended the marketers and advertisers to consider more frequency of ad exposures if they want optimal outcomes for building brand sustainability [113-115]. Hence, on the basis of discussions and previous literature, the researchers have formulated the following hypotheses:

Hypothesis 7A (H7A). Duration of advertisement mediates email marketing tool and effectiveness of digital media advertising for building brand sustainability.

Hypothesis 7B (H7B). Duration of advertisement mediates mobile phone marketing tools and effectiveness of digital media advertising for building brand sustainability.

Hypothesis 7C (H7C). Duration of advertisement mediates search engines optimization and companies' websites marketing channels and effectiveness of digital media advertising for building brand sustainability.

Hypothesis 7D (H7D). Duration of advertisement mediates social media marketing channels and effectiveness of digital media advertising for building brand sustainability.

\subsubsection{Quality of Content of the Advertisement and Online Digital Media Advertising}

The content is one of the crucial components, which sticks to the consumer for a while and, eventually, this may cause the retention and brand loyalty of the consumer. The contents of the ad comprise of different characteristics, such as title/feature/body, and contact, etc. [115]. The quality 
of ad content is the fundamental piece of the composed ad, which gives a significant drawing of the promotion for building brand sustainability. Content has different components, including the design (textual style write or estimate), content sum (number of words), and the measure of data [116]. In the quality of contents for any ad, it additionally incorporates information regarding the brand, organization, and contact information. This idea is exceptionally successful for the advertising and promotion of brands and services for an organization. McCoy et al. [95], and Pieters and Wedel [98] have examined three essential components (brand, picture, and content) for drawing the attention of consumer to promote any service or product. They promote the content as the key component in catching the purchasers' consideration. Pieters and Wedel [98] also concluded that the content features are considered the benchmark for the effectiveness of any online ad. According to Cox [116], the promotional incentives for the banner ads have a higher click-through rate, similarly, Xie et al. [99] demonstrated that the incentives improve the higher-click-through rate, but it also depends on the sort of appeal, either it is rational or emotional. The banner advertisements that provide samples gained the less high-click-through rate than the ads, which contain the detailed information $[117,118]$. Thus, on the basis of discussions and previous literature, the researchers have formulated the following hypotheses:

Hypothesis 8 (H8A). Quality of content mediates email marketing tool and effectiveness of digital media advertising for building brand sustainability.

Hypothesis 8 (H8B). Quality of content mediates mobile phone marketing tools and effectiveness of digital media advertising for building brand sustainability.

Hypothesis 8 (H8C). Quality of content mediates search engines optimization and companies' websites marketing channels and the effectiveness of digital media advertising for building brand sustainability.

Hypothesis 8 (H8D). Quality of content mediates social media marketing channels and the effectiveness of digital media advertising for building brand sustainability.

\subsubsection{Customers' Attitude and Online Digital Media Advertising}

The former literature was used to craft an attitude of consumer towards digital marketing messages and communication channels as well. There are two main types of consumer value, utilitarian, and hedonic. Utilitarian value refers to the instrumental or practical value, such as product quality or the ability to effectively perform a task [119]. Hedonic value includes an effective component and it accounts for the experiential value based on an effective definition of experience. In an empirical study, the role experiential features in relation to product success of a selection of well-known products were tested [25,119-121]. The results showed that the experiential features contribute to the value recognized by customers. This confirms that customers are not purely rational. Simultaneously, the customers did not neglect function. The products that included some sort of practical use had to live up to a required standard and they have certain functional features to enable optimal experience [122]. For these products, the study concludes that it is optimal to deliver a balance between the utilitarian and hedonic value. The appropriate weight of utilitarian versus hedonic value would depend on the given product $[65,123]$. Therefore, on the basis of previous literature, the following hypotheses have been developed:

Hypothesis 9 (H9A). Customer attitude mediates email marketing tool and effectiveness of digital media advertising for building brand sustainability.

Hypothesis 9 (H9B). Customer attitude mediates mobile phone marketing tools and the effectiveness of digital media advertising for building brand sustainability. 
Hypothesis 9 (H9C). Customer attitude mediates search engines optimization and companies' websites marketing channels and the effectiveness of digital media advertising for building brand sustainability.

Hypothesis 9 (H9D). Customer attitude mediates social media marketing channels and the effectiveness of digital media advertising for building brand sustainability.

\subsubsection{Brand Loyalty and Online Digital Media Advertising}

According to Bennett and Rundle-Thiele [105], Chaudhuri and Halbrook [106], and Oliver [107], the researchers and practitioners have given paramount attention to building and maintaining brand loyalty. According to Keller [108], brand loyalty can be abstracted as the last measurement of customer mark reverberation symbolizing the customers' definitive relationship and the level of distinguishing proof with the brand. As brands enhance positive, selective, and prominence in the minds of customers, and win the loyalty of customers that help for building brand sustainability $[124,125]$. According to Frambach et al. [111] and Brito [112], the Google has transformed the system of its search context to empower to customers, thus, in this way, the Google providing refreshed and relevant material that enhances the customers' confidence and loyalty for the brands. There are several platforms for interacting with the customers, and it is difficult for marketers to simultaneously choose all of the platforms, thus, they select the best one to speak with the customers [126]. Moreover, offering flexible functions enable customers to draw in with the brand consistent and build brand loyal. Thus, on the basis of above discussions and previous literature, we have developed the following hypotheses for the mediating role of brand loyalty between exogenous variables and effectiveness of online digital media advertising for building brand sustainability [49,127]:

Hypothesis 10 (H10A). Brand loyalty mediates email marketing tool and effectiveness of digital media advertising for building brand sustainability.

Hypothesis 10 (H10B). Brand loyalty mediates mobile phone marketing tools and effectiveness of digital media advertising for building brand sustainability.

Hypothesis 10 (H10C). Brand loyalty mediates search engines optimization and companies' websites marketing channels and the effectiveness of digital media advertising for building brand sustainability.

Hypothesis 10 (H10D). Brand loyalty mediates social media marketing channels and effectiveness of digital media advertising for building brand sustainability.

\subsubsection{Previous Purchase Experience and Online Digital Media Advertising}

On the organizational level, the customer experience is about managing the relations to the customer and their interactions with the company. Consistency across these interactions is important for the total experience, interacting with a company is part of any customer relation. However, when addressing customer experience, an emotional part is often included due to the belief that customers are not purely rational [128]. In terms of maintaining loyalty, emotional bonds are both harder to imitate and sever [129]. It is argued that this leads to long-lasting loyalty and that a 'ladder of customer loyalty' is a function of the total customer experience [130]. Only improving one aspect of the customer experience is not likely to deliver the full experience that customer's desire $[130,131]$. While the consumption emotions are elicited in the post-purchase phase, it cannot be seen in isolation from the rest of the customer journey. Satisfaction literature commonly addresses the influence of expectations in relation to product performance; however, there are also more emotional and imaginative aspects to consider. Richins [118] claims that the cognitive and affective process has the consumer before acquisition influence the magnitude and nature of the experienced emotion after acquisition [122-125]. These thoughts and emotions are carried over in the post-purchase stage, where they influence the 
emotions during consumption. When understanding how to elicit such a response, one can deliberately 'design for experience'. Being seen in relation to the broader construct of customer experience already discussed, product experience is more specifically focused on the brand and its user, which is ultimately helpful for building brand sustainability $[49,131]$. Therefore, on the basis of previous literature, the following hypotheses have been developed:

Hypothesis 11 (H11A). Previous purchase experience mediates email marketing tool and effectiveness of digital media advertising for building brand sustainability.

Hypothesis 11 (H11B). Previous purchase experience mediates mobile phone marketing tools and effectiveness of digital media advertising for building brand sustainability.

Hypothesis 11 (H11C). Previous purchase experience mediates search engines optimization and companies' websites marketing channels and the effectiveness of digital media advertising for building brand sustainability.

Hypothesis 11 (H11D). Previous purchase experience mediates social media marketing channels and the effectiveness of digital media advertising for building brand sustainability.

\subsubsection{Word of Mouth and Effectiveness of Online Digital Media Advertising}

FMCGs and services organizations are serving their customers by providing quick feedback and the best information about products and services. The satisfied customer can spread the positive word of mouth that certainly presents a great advantage in that it promotes consumer depiction and awareness [132]. Leigh and Gabel [121] and Groeger and Buttle [122] showed that a demonstrable word of mouth is more efficacious when compared with the advertising. Çizmeci and Eracan [49] and Murtiasish et al. [123] have effectively considered and finished up a confirmed impact of word of mouth on brand awareness and brand sustainability. According to Herr et al. [124], the positive word of mouth has a critical effect on positive brand advertising. As indicated by Vivilaite et al. [125], the positive data go by the client about the brand has a huge and positive and important impact on advertising. Likewise, Cornelissen [126] additionally demonstrated in their investigations that word of mouth is a huge arbiter between intuitive online media and brand advertising. SMS promoting has a greater effect than traditional advertising in connection to brand awareness [132]. As per Morgan et al. [128] and Goldenberg et al. [129], these days, word of mouth plays an extremely pertinent role in online media on the grounds that the purchasers share their encounters subsequent to utilizing any item; this makes the positive effect on advertising and brand sustainability. In this way, now, in light of the discussed literature, the researchers have formulated the following hypotheses between online digital media channels and word of mouth:

Hypothesis 12 (H12A). Word of mouth mediates email marketing tool and the effectiveness of digital media advertising for building brand sustainability.

Hypothesis 12 (H12B). Word of mouth mediates mobile phone marketing tools and effectiveness of digital media advertising for building brand sustainability.

Hypothesis 12 (H12C). Word of mouth mediates search engines optimization and companies' websites marketing channels and the effectiveness of digital media advertising for building brand sustainability.

Hypothesis 12 (H12D). Word of mouth mediates social media marketing channels and the effectiveness of digital media advertising for building brand sustainability. 


\subsection{Moderating Variables and Hypotheses Formulation}

Marketers are facing cutthroat competition from the rivals, as the customers have ample choices available to decide about the brand to purchase $[132,133]$. The technology is paramount in this new kind of online media, thus we have taken innovation in information technology and its two dimensions, and innovation in telecommunication technology, and it has two dimensions, as follows.

\subsubsection{Innovations in Information Technology and the Effectiveness of Digital Media Advertising}

The technological development in information technology changes very rapidly, such as in hours, not in weeks or months, thus, the significance of IT is manifolds for interactive online digital media advertising. Colrain and Zuppo [132] have suggested an ICT hierarchical model; Ziden et al. [133] have further demonstrated that every level of the hierarchy "contains some degree of commonality in that they are related to technologies that facilitate the transfer of information and various types of electronically mediated communications". According to Chandler and Munday [134], numerous industrial sectors are associated with information technology, for instance, e-commerce, telecom equipment, computer software, and computer hardware, etc. Currently, the Internet is a backbone of information technology that has transformed the marketing communication in an effective way around the globe, thus this technology has provided the ease to the consumers to reach out significantly towards a large number of brands at one-click [134]. According to Chitra and Sasikala [27], Çizmeci and Ercan [49], Blair [88], and Montgomery and Chester [135], the information technology has provided the vast mass communication channels to the advertisers and marketers for the promotion and brand awareness of their brands, so, in this way, the information technology is considered as a powerful moderator. Thus, on the basis of the above discussions and previous literature, we have developed the following hypotheses for the moderating role of innovation in information technologies between exogenous variables and effectiveness of online digital media advertising for building brand sustainability [136,137]:

Hypothesis 13 (H13A). Innovation in information technology moderates email marketing channel, and effectiveness of digital media advertising for building brand sustainability.

Hypothesis 13 (H13B). Innovation in information technology moderates mobile phone marketing media tool, and effectiveness of digital media advertising for building brand sustainability.

Hypothesis 13 (H13C). Innovation in information technology moderates search engines optimization and companies' websites marketing, and effectiveness of digital media advertising for building brand sustainability.

Hypothesis 13 (H13D). Innovation in information technology moderates social media marketing, and effectiveness of digital media advertising for building brand sustainability.

\subsubsection{Processors' Speed and Effectiveness of Online Digital MEDIA advertising}

In the arena of e-business, it is still imperative as the applications of e-business become more complicated as websites combine more rich media, for instance, video and audio [138]. The content of the site needs to download within a few seconds; otherwise, the credibility of the site would be hampered. This research further concluded that the poor performance of the website reduces to visitors by up to $64 \%$ and reduces e-business activities by $62 \%$. If there will not be significant crowd for accessing the particular website, then there will not be any delay in fetching information [139]. On the contrary, if there would be an enormous crowd for accessing that particular website, then there will be significant delay in downloading the requested pages, thus, in this condition, both web server software and hardware have to cope up the problem [140]. The speed of a network connection also administers the download speed, the network connection speed generally, illustrious as "the bandwidth". If the size of the bandwidth would be higher, then there will be a greater flow of information to the 
consumer $[80,141]$. Therefore, in this way, the speed of processors provides more ease for the consumers to download web-pages, which is ultimately beneficial for online digital advertising [49,140-142]. Thus, on the basis of the above discussions and previous literature, we have developed the following hypotheses for the moderating role of speed of processors between the exogenous variables and effectiveness of online digital media advertising for building brand sustainability:

Hypothesis 14 (H14A). Processors speed moderates email marketing media tool and effectiveness of digital media advertising for building brand sustainability.

Hypothesis 14 (H14B). Processors speed moderates mobile phone media tools, and effectiveness of digital media advertising for building brand sustainability.

Hypothesis 14 (H14C). Processors speed moderates search engines optimization and companies' websites and effectiveness of digital media advertising for building brand sustainability.

Hypothesis 14 (H14D). Processors speed moderates social media channels and effectiveness of digital media advertising for building brand sustainability.

\subsubsection{Fiber-Optic Internet and Online Digital ONLINE media Advertising}

Fiber broadband is the fastest method of delivering high-speed Internet to homes and businesses. Consumers think of fiber as a new technology, but the Internet "backbone" network that connects cities and countries has been built with fiber optic cables since the emergence of the Internet [143]. Fiber to the home, or FTTH as it is generally referred to, is the best quality level of private Internet providers; it is nothing unexpected that fiber optics is the fastest type of broadband innovation [141-143]. The speedy and flawless information and data could be downloaded since fiber optics Internet is the speediest Internet accessible $[80,140]$. The major benefits of fiber optics Internet are: (1) Fiber is quicker than normal broadband speeds, (2) Download is now quicker with fiber-optics Internet, and (3) Fiber Internet is more reliable than copper and less 'inconsistent' than Wi-Fi. New fiber providers, such as, Google Fiber has arrived in the market and is providing aspiring plans, which is a turning point in online advertising due to its exceptional speed [49]. At speeds up to one Gigabit for each second, fiber Internet transports much faster downloads than broadband. Thus, this exceptional speed provides greater ease to the consumers to use in online buying processes, which opens up new doors of online advertising to the marketing practitioners and advertisers to the diverse sectors of the industries $[25,80]$. Thus, on the basis of the above discussions and previous literature, the researchers have formulated the following hypotheses:

Hypothesis 15 (H15A). Fiber optic Internet moderates email marketing media tool, and effectiveness of digital media advertising for building brand sustainability.

Hypothesis 15 (H15B). Fiber optic Internet moderates mobile phone media tools, and effectiveness of digital media advertising for building brand sustainability.

Hypothesis 15 (H15C). Fiber optic Internet moderates search engines optimization and companies' websites, and effectiveness of digital media advertising for building brand sustainability.

Hypothesis 15 (H15D). Fiber optic Internet moderates social media channels, and effectiveness of digital media advertising for building brand sustainability. 


\subsubsection{Innovations in Telecommunication Technology and Online Digital Media and Advertising}

The new interactive media is a form of new communication, which combined the telecommunication technologies, smartphones, and computers with the help of the Internet. These telecommunication technologies are used as new channels for the dissemination of messages, data, and information to the heterogeneous audience, irrespective of time, space, and location. According to Ahmed et al. [80], this new interactive media has been formed with the new dimensions of telecommunication and information technologies, which comprises of the Internet, smartphones, email, video conferencing, online magazines and newspapers, and chat rooms, etc. The old and traditional media has been transformed into the new interactive digital media with the help of digital computing and digital communication devices, and has become more potent for the advertising industry $[25,143]$. The use of this new interactive media in advertising has enhanced the reach and it spans to the online consumers across the globe. This new form of media has been used in effective promotional and advertising campaigns of almost every industrial and services sectors [141-143]. The growing trend of new interactive media technologies has provided the new avenues of advertising to the advertising practitioners and marketers to target more consumers in an effective and inexpensive way for building brand sustainability $[50,142]$. Thus, on the basis of above discussions and previous literature, we have developed the following hypotheses for the moderating role of telecommunication technologies innovations between the exogenous variables and effectiveness of online digital media advertising for building brand sustainability:

Hypothesis 16 (H16A). Innovation in telecommunication technologies moderates' email marketing media tool, and effectiveness of digital media advertising for building brand sustainability.

Hypothesis 16 (H16B). Innovation in telecommunication technologies moderates' mobile phone media tools, and effectiveness of digital media advertising for building brand sustainability.

Hypothesis 16 (H16C). Innovation in telecommunication technologies moderates' search engines optimization and companies' websites, and the effectiveness of digital media advertising for building brand sustainability.

Hypothesis 16 (H16D). Innovation in telecommunication technologies moderates' social media channels, and the effectiveness of digital media advertising for building brand sustainability.

\subsubsection{The Smartphone and Online Digital Media Advertising}

According to Ahmed et al. [80], "Mobile phones that contain default applications and having the more advanced features of the Internet ( $3 \mathrm{G}$ and $4 \mathrm{G}$ ) than the traditional one, called Smartphone. Smartphone performs more functions apart of texting and calling and it has a very advanced way of interaction than that of the old one [49]. The rapid changes in the digital marketing technology have transformed the smartphone product, like their life cycles, as contrasted than earlier, like Android, Windows Phone, etc., as the advancement occurs. This change in technology has boosted the use of smartphones, and consumers are using all the time of these smartphones for satisfying their desires, except "The Calling". Many organizations, including Pepsi and Co., Subway Kellogg's, Burger King, and McDonald use the mobile marketing strategy. The mobile phone advertising strategy is more result oriented than the online feature of the Internet so most of the companies prefers the smartphone advertising strategy [135-140]. According to Holzer and Ondrus [139], all these software are especially made for mobile phones apps and are sometimes already installed on smartphones, and sometimes it could be installed by downloading it from the host companies' websites. All of these Mobile apps usually advanced and developed the in-house production or sometimes through outsourcing $[138,139]$. The consumers of smartphone use the apps to order specific services via easy approach that was provided by the app to get access to the particular producer [142]. It is reported that more than one app is used in one smartphone and it is expected that 55 billion spent on apps may be downloaded [143]. 
Thus, based on the above discussions and previous literature, it is very clear that the smartphones are the one of most significant hi-tech dynamics, which performs a very pertinent part in digital media marketing channels, and help marketers to make and execute effective marketing communication strategies for increasing the effectiveness of online digital media advertising for building brand sustainability. Hence, we have formulated the following hypotheses on the basis of previous literature:

Hypothesis 17 (H17A). Smartphone moderates email marketing tools, and effectiveness of digital media advertising for building brand sustainability.

Hypothesis 17 (H17B). Smartphone moderates mobile phone marketing media tool, and effectiveness of digital media advertising for building brand sustainability.

Hypothesis 17 (H17C). Smartphone moderates search engines optimization and companies' websites marketing, and effectiveness of digital media advertising for building brand sustainability.

Hypothesis 17 (H17D). Smartphone moderates social media marketing channels, and effectiveness of digital media advertising for building brand sustainability.

\subsubsection{Generations (1G-5G) of Wireless Technologies and Online Digital Media Advertising}

The mobile wireless sector has begun its technology invention, revolution, and evolution since the beginning of the 1970s, for last few decades, mobile wireless technology has been categorized according to its generation, which mainly signifies the kind of data transfer speed and the types of services of every classification of technologies [142]. The Nippon Telephone and Telegraph (NTT) has initiated 1G technologies in Japan, and it was introduced in Europe two years later, but this technology was not capable of operating between countries, thus it was the big drawback of this technology [143]. Later on, 2.75G or enhanced data rates GSM evolution technology (EDGE) has been introduced, which allows for the fastest and clear transmission of the information and data. The 3G-3.75G technologies were introduced that offers more innovative facilities, like video calls, broad wireless data transfer, and WAW services. Now, the $4 \mathrm{G}$ technologies have been used commercially all over the world, offering more bandwidth speed, excessive quality video, and audio streaming [138-142]. The five-generation $(5 G)$ is significant for the portable media communication. Several research studies have demonstrated the positive impact of these technologies in creating more avenues of brand awareness, brand loyalty, and brand sustainability by using online media channels $[49,80,110]$. Thus, on the basis of the above discussions and previous literature, we have developed the following hypotheses for the moderating role of generation technologies (1G-5G) between exogenous variables and the effectiveness of online digital media advertising for building brand sustainability:

Hypothesis 18 (H18A). Generation wireless technology (1G-5G) moderates email marketing media tool, and effectiveness of digital media advertising for building brand sustainability.

Hypothesis 18 (H18B). Generation wireless technology (1G-5G) moderates mobile phone media tools, and effectiveness of digital media advertising for building brand sustainability.

Hypothesis 18 (H18C). Generation wireless technology (1G-5G) moderates search engines optimization and companies' websites, and effectiveness of digital media advertising for building brand sustainability.

Hypothesis 18 (H18D). Generation wireless technology (1G-5G) moderates social media channels, and the effectiveness of digital media advertising for building brand sustainability. 


\subsection{The Conceptual Framework of the Research Model}

Finally, based on the above discussions and previous literature, as mentioned in the previous section, the researchers have constructed a conceptual framework of the research model, which is depicted in Figure A1 as shown in Appendix A.

\section{Materials and Methods}

\subsection{Research Design and Measurements Selection}

This research is quantitative and data was collected through structured questionnaire. Data was collected from both primary and secondary sources, for primary data, the researchers have devised a self-structured, but partially adapted items from Ahmed et al. [11], Filipovic [42], and Geçti and Gümüş [43], Çïzmecï and Ercan [49], and Blair [88] etc., and used five points Likert scale and get the responses from the professionals of different sectors of the manufacturing and services sectors of Karachi city, the researchers also collected primary responses from consumers and customers. The secondary data has been collected from different sources, like research Journals, newspapers, dissertations, books, and Internet sources, which was properly cited throughout the research study.

\subsection{Sampling Technique and Sample Size}

Researchers have used a purposive sampling technique for the collection of data due to the infinite sampling framework of consumers and for the representative sample. The researchers have collected data through structured questionnaire in person, and through email, we have given the questionnaire as File 1 in the Supplementary Materials. Initially, researchers have taken responses from 950 individuals, but 40 responses were found to be incomplete and inappropriate. Thus, the final selected sample size was 910 respondents from the corporate sector and consumers from the mentioned five important markets of Karachi city. The samples comprise of marketers and brand managers, entrepreneurs, middle and upper-level managers, students, teachers, doctors, patients, fashion designers, TV and film producers and artists, finance personnel, HR staff, bankers, stock brokers, real estate developers, and common household consumers of these online brands.

\subsection{Statistical Techniques for Estimation}

We have used several methods, such as for the descriptive analysis we employed descriptive statistics, for the analysis of data. We employed exploratory factor analysis (EFA) for the validation and reduction of items and factors. In EFA we employed the rotated component matrix method, KMO and Bartlett's Sphericity analysis, and the total variance explained method. In the SEM-Based approach, we employed structural equation modeling, and confirmatory factor analysis for the examination of reliabilities, Cronbach's alphas, composite reliabilities, convergent validities, and divergent validities. Finally, we employed the Hayes process modelling for the analysis of direct hypothesized relationship, and also to investigate the indirect hypothesized relationship, such as mediation and moderation. We have also shown three-dimensional (3D) graphical presentations to confirm the moderation analysis. We further define all of these statistical techniques in the estimations and results sections.

\subsection{Sample Description}

Nine hundred and fifty (950) respondents of all the groups were attempted to get responses; however, 910 responses were properly answered on a voluntary basis. Thus, in this way, the response rate was $95.79 \%$. According to Anderson and Gerbing [144], the sample size is adequate for structural equation modelling. The income is given in Pakistani rupee (PKR), and complete profile of respondents is exhibited in Table 1. 
Table 1. Profile of Respondents.

\begin{tabular}{|c|c|c|c|}
\hline \multicolumn{2}{|c|}{ Demographics } & \multirow{2}{*}{$\begin{array}{c}\text { Frequency } \\
515\end{array}$} & \multirow{2}{*}{$\begin{array}{c}\text { Percent } \\
56.6 \%\end{array}$} \\
\hline & Male & & \\
\hline & Female & 395 & $43.4 \%$ \\
\hline \multirow{3}{*}{ Marital Status } & Single & 522 & $57.4 \%$ \\
\hline & Married & 362 & $39.8 \%$ \\
\hline & Divorced & 26 & $2.9 \%$ \\
\hline \multirow{5}{*}{ Age (In Years) } & $18-30$ & 323 & $35.5 \%$ \\
\hline & $30-40$ & 206 & $22.6 \%$ \\
\hline & $40-50$ & 124 & $13.6 \%$ \\
\hline & $50-60$ & 144 & $15.8 \%$ \\
\hline & More than 60 & 113 & $12.4 \%$ \\
\hline \multirow{4}{*}{ Education } & High School diploma & 395 & $43.4 \%$ \\
\hline & Graduation & 289 & $31.8 \%$ \\
\hline & Post-Graduation & 146 & $16.0 \%$ \\
\hline & Professional degree & 80 & $8.8 \%$ \\
\hline \multirow{5}{*}{ Experience (In Years) } & $1-5$ & 244 & $26.8 \%$ \\
\hline & $5-10$ & 273 & $30.0 \%$ \\
\hline & $10-15$ & 126 & $13.8 \%$ \\
\hline & 15-20 & 121 & $13.3 \%$ \\
\hline & More than 20 & 146 & $16.0 \%$ \\
\hline \multirow{5}{*}{ Income (In PKR 000) } & $10-30 \mathrm{~K}$ & 158 & $17.4 \%$ \\
\hline & $30-50 \mathrm{~K}$ & 403 & $44.3 \%$ \\
\hline & $50-70 \mathrm{~K}$ & 187 & $20.5 \%$ \\
\hline & $70-90 \mathrm{~K}$ & 98 & $10.8 \%$ \\
\hline & More than $90 \mathrm{~K}$ & 64 & $7.0 \%$ \\
\hline \multicolumn{2}{|c|}{ Total-N } & \multicolumn{2}{|c|}{910} \\
\hline
\end{tabular}

\section{Estimations of Results}

\subsection{Descriptive Statistics for Operational Constructs}

According to Huang et al. [145], the normality pattern of sample data is a pre-requisite for employing structural equation modeling and multiple regression analysis. Thus, we have converted data into a standardized Z-score for checking the normality pattern. The outcomes exhibit that all of the responses are within the prescribed bracket of \pm 3.5 ; moreover, the standard deviation, skewness for each construct and variable within the range of \pm 1.5 , and Kurtosis is within the range of \pm 3 . According to Ahmed et al. [11], Rutherford et al. [146], and Byrne [147], these ranges substantiated the normality pattern of the sample data.

\subsection{Exploratory Factor Analysis-EFA}

The exploratory factor analysis (EFA) is the process of lessening the preliminary number of factors and items, since if there were a huge number of variables initially, then it should be reduced up to an applicable number of factors and items. It is very difficult to analyze and interpret the huge numbers of factors and items; thus, to reduce into a smaller number of factors and items through EFA. In exploratory factor analysis, the variables will not be categorized into independent, dependent, and any other kind of variables; they just simply take account of the dependence relationship for the appropriateness. Exploratory factor analysis comprises of several tests, such as the anti-mage correlation method, Bartlett's test of Sphericity, principal component analysis, KMO analysis, and total variance explained. 


\subsection{Kaiser-Meyer-Olkin and Bartlett's' Sphericity Tests}

In exploratory factor analysis for measuring the sampling tolerability, the researchers have employed the Kaiser-Meyer-Olkin (KMO) approach. Table 2 demonstrated the outcomes of the $\mathrm{KMO}$ value for the considered variables, which is $0.880(88.00 \%)$, which showed the precision of the considered sample for this research, which is considered to be very good in comparison to $0.50(50 \%)$, the cut-off value. Similarly, the outcome of Bartlett's Sphericity exhibited that the value of probability is less than $0.05(p<0.05)$, which established that there is significant variation in the identity matrices and correlation properties [148]. Thus, the result of Bartlett's Sphericity has been statistically significant at $1 \%$, now, on the basis of these results; researchers can proceed for further analysis [149].

Table 2. Outcomes of Kaiser-Meyer-Olkin (KMO) and Bartlett's tests.

\begin{tabular}{ccc}
\hline \multicolumn{3}{c}{ KMO and Bartlett's Test } \\
\hline \multicolumn{3}{c}{ Kaiser-Meyer-Olkin Measure of Sampling Adequacy } \\
\hline \multirow{3}{*}{ Bartlett's Test of Sphericity } & Approx. Chi-Square & 0.880 \\
& Df & $50,899.51$ \\
& Sig. & 253 \\
&
\end{tabular}

\subsection{Total Variance Explained}

The total variance explains the variance panel among the potential variables or factors, since there are nineteen (19) factors or variables and fifty-seven (57) components. The Eigenvalues explain the effectiveness of variables; the cut-off values should be more than one for all of the variables in terms of Eigenvalues. The outcomes exhibited that all nineteen (19) factors have the Eigenvalue of more than 1. The outcomes further demonstrated that these nineteen variables have $86.10 \%$ cumulative variance, which is considered to be very good against the cut-off value of $60 \%$. Thus, the researchers have taken all 19 variables and 57 items for their analysis of this research study.

\subsection{Rotated Component Matrix (Principal Component Analysis)}

The researchers have used exploratory factor analysis (EFA) for the substantiation of all the items of independent, mediating, moderating, and dependent variables. The EFA converts a higher set of factors to the lower set of factors; thus, for this reason researchers have used principal component analysis with Varimax rotation approach [11,147]. In the questionnaire of this study, the researchers have considered the total of 57 items for 19 variables, including dependent, independent, moderating, and mediating variables. The researchers have used four independent variables with 12 constructs, a dependent variable with three constructs, eight mediating variables with 24 items, and six moderating variables with 18 constructs. The results of an interrelationship between the constructs and factors have been demonstrated in the principal component analysis, as exhibited by Table A1 in Appendix A. The outcomes of principal component examination established that each set of variables has more than 0.50 values, thus, the researchers can take all of the construct and variables for the undertaken study. According to Kaiser [150], factor analysis (FA) was considered to be significant in order to select or deselect the variables and items.

\subsection{Reliabilities, Validities, and AVE of Variables and Constructs}

The reliabilities are considered to be very good if $\alpha \geq 0.90$, good if $\alpha \geq 0.80$, and satisfactory if $\alpha \geq 0.70$, and these values were measured as a threshold [147]. The outcomes of Table 3 exhibited that the composite and Cronbach's reliabilities followed these cut-off values, and these results have shown that all of the variables and constructs also have internal consistency. It is also confirmed from the results of the average variance extracted that the square root of AVE for every variable and construct showed the values are greater than 0.50 , so these factors and constructs also have good construct validities, which are also the requirement for structural equation modeling [151]. The requirement 
for discriminant validity has been achieved from the outcomes of factor loading for each item that demonstrated the values are between 0.70-0.90, as shown in Table A1 in Appendix A. According to Hsieh and Hiang [152] and Huang et al. [145], discriminant validity is a fundamental need for structural equation modeling. The results of the rotated component matrix of Table A1 in Appendix A demonstrated that each set of items have the inter-correlation values are greater than 0.50 , which vindicated the individuality of items for the convergent validity. The individual outcome of average variance extracted (AVE) further justified the convergent validity, because each item of a variable has greater than 0.50 values, as demonstrated in Table $3[153,154]$. 
Table 3. Reliabilities, Average Variance Extracted (AVE), and Factor Loading of operational constructs.

\begin{tabular}{|c|c|c|c|c|c|}
\hline Factors & Operational Constructs & Factor Loading & Cronbach's Alpha & Composite Reliability & AVE \\
\hline \multirow{3}{*}{$\begin{array}{c}\text { Online Digital Media } \\
\text { Advertising }\end{array}$} & ODA1 & 0.837 & \multirow{3}{*}{0.902} & \multirow{3}{*}{0.887} & \multirow{3}{*}{0.724} \\
\hline & ODA2 & 0.736 & & & \\
\hline & ODA3 & 0.881 & & & \\
\hline \multirow{3}{*}{ Email Marketing } & EM1 & 0.742 & \multirow{3}{*}{0.871} & \multirow{3}{*}{0.834} & \multirow{3}{*}{0.628} \\
\hline & EM2 & 0.827 & & & \\
\hline & EM3 & 0.805 & & & \\
\hline \multirow{3}{*}{$\begin{array}{l}\text { Mobile Phone } \\
\text { Marketing }\end{array}$} & MPM1 & 0.842 & \multirow{3}{*}{0.927} & \multirow{3}{*}{0.893} & \multirow{3}{*}{0.736} \\
\hline & MPM2 & 0.827 & & & \\
\hline & MPM3 & 0.902 & & & \\
\hline \multirow{3}{*}{$\begin{array}{l}\text { SEO and CW } \\
\text { Marketing }\end{array}$} & SEOCW1 & 0.842 & \multirow{3}{*}{0.893} & \multirow{3}{*}{0.864} & \multirow{3}{*}{0.679} \\
\hline & SEOCW2 & 0.827 & & & \\
\hline & SEOCW3 & 0.802 & & & \\
\hline \multirow{3}{*}{$\begin{array}{l}\text { Social Media } \\
\text { Marketing }\end{array}$} & SMM1 & 0.827 & & & \\
\hline & SMM2 & 0.922 & 0.925 & 0.887 & 0.724 \\
\hline & SMM3 & 0.798 & & & \\
\hline & COA1 & 0.837 & & & \\
\hline Characteristics of & $\mathrm{COA} 2$ & 0.728 & 0.862 & 0.833 & 0.625 \\
\hline & COA3 & 0.803 & & & \\
\hline & DSA1 & 0.735 & & & \\
\hline Design of & DSA2 & 0.735 & 0.852 & 0.803 & 0.577 \\
\hline & DSA3 & 0.806 & & & \\
\hline & DUA1 & 0.749 & & & \\
\hline Duration of & DUA2 & 0.829 & 0.889 & 0.846 & 0.645 \\
\hline & DUA3 & 0.832 & & & \\
\hline & QCA1 & 0.738 & & & \\
\hline Quality Content of & QCA2 & 0.831 & 0.901 & 0.845 & 0.644 \\
\hline Advertisement & QCA3 & 0.843 & & & \\
\hline & CA1 & 0.831 & & & \\
\hline Customer Attitude & CA2 & 0.923 & 0.922 & 0.888 & 0.726 \\
\hline & CA3 & 0.797 & & & \\
\hline & BLO1 & 0.841 & & & \\
\hline Brand Loyalty & $\mathrm{BLO} 2$ & 0.736 & 0.858 & 0.838 & 0.634 \\
\hline & BLO3 & 0.808 & & & \\
\hline Previous Purchase & PPE1 & 0.731 & & & \\
\hline $\begin{array}{l}\text { Previous Purchase } \\
\text { Experience }\end{array}$ & PPE2 & 0.838 & 0.897 & 0.846 & 0.649 \\
\hline & PPE3 & 0.842 & & & \\
\hline & WOM1 & 0.828 & & & \\
\hline Word of Mouth & WOM2 & 0.826 & 0.912 & 0.889 & 0.727 \\
\hline & WOM3 & 0.902 & & & \\
\hline Innovation in & IIT1 & 0.728 & & & \\
\hline Information & IIT2 & 0.825 & 0.896 & 0.831 & 0.622 \\
\hline Technology & IIT3 & 0.809 & & & \\
\hline & FOI1 & 0.728 & & & \\
\hline Fiber Optics Internet & FOI2 & 0.822 & 0.882 & 0.834 & 0.627 \\
\hline & FOI3 & 0.821 & & & \\
\hline & SOP1 & 0.826 & & & \\
\hline Speed of Processors & SOP2 & 0.921 & 0.928 & 0.887 & 0.724 \\
\hline & SOP3 & 0.801 & & & \\
\hline Innovation in & ITT1 & 0.821 & & & \\
\hline Telecomm. & ITT2 & 0.819 & 0.899 & 0.865 & 0.680 \\
\hline Technology & ITT3 & 0.834 & & & \\
\hline & SMP1 & 0.829 & & & \\
\hline Smartphones & SMP2 & 0.812 & 0.892 & 0.849 & 0.654 \\
\hline & SMP3 & 0.782 & & & \\
\hline & GTT1 & 0.725 & & & \\
\hline Generation (IG-5G) & GTT2 & 0.816 & 0.871 & 0.823 & 0.608 \\
\hline lelecom. lechnology & GTT3 & 0.796 & & & \\
\hline
\end{tabular}

Note: ODA = Online digital advertising; EM = Email marketing; MPM = Mobile phone marketing; SCWM = Search engine optimization and companies' websites marketing; $\mathrm{SMM}=$ Social media marketing; $\mathrm{COA}=$ Characteristics of advertising; DSA = Design of advertising; DUA = Duration of advertising; $\mathrm{QCA}=$ Quality content advertising; $\mathrm{CA}=$ Customer attitude; $\mathrm{PPE}=$ Previous purchase experience; $\mathrm{WOM}=$ Word of mouth; $\mathrm{IIT}=$ Innovation in information technology; FOI = Fiber optics Internet technology; SOP = Speed of processors; ITT = Innovation in Telecommunication technology; SMP = Smartphone technology; GTT = Generation (1G-5G) technologies. 


\subsection{Structural Equation Modelling}

According to the theory of structural equation modeling, the results of the considered fit indices for structural and measurement, models are presented in Table A2 in Appendix A. We have taken 57 constructs for 19 variables in our structured and measured models. The researchers have constructed the model by taking one dependent variable (online digital media) with three operational constructs, four independent variables, such as email marketing, with three operational constructs, mobile phone marketing with three constructs, search engine optimization and companies' websites with three operational constructs, and social media marketing with three operational constructs. Moreover, researchers have taken eight mediating variables, such as characteristics of advertising, the design of advertising, duration of advertising, quality content advertising, customer attitude, previous purchase experience, brand loyalty, and word of mouth, and each variable has three operational items. Finally, the researchers have considered six moderating variables, such as innovation in information technology, fiber optics Internet technology, the speed of processors, innovation in telecommunication technology, smartphone technology, and generation (1G-5G) technologies, in which every moderating variable have three operational constructs. Table A2 in Appendix A exhibited the summarized results of structural and measurement models for all of the factors and items, which followed the cut-offs, such as Parsimonious fit indices (PCFI $>0.75$, PGFI $>0.75$ and PNFI $>0.75$ ), absolute fit indices (GFI $>0.95$, $\chi^{2}-$ low, probability $<0.05, \chi^{2} /$ df-relative $\chi^{2}<5.0$ ), relative fit-indices (NFI $>0.90$, IFI $>0.95$, TLI $>0.95$ ), and Non-centrality based fit indices (RNI $>0.95$, CFI $>0.95$ and RMSEA $<0.05$ ) that specifies the good model fitness [154,155].

\subsection{Confirmatory Factor Analysis}

We have used confirmatory factor analysis (CFA) to validate the considered factors and indicators on the basis of prior theory [11,153-155]. According to Byrne [147] and Meyers et al. [156], there are more than twenty (20) fit indices, and there is no consensus as to which and how many are to be reported to measure the hypothesized model. Table A2 in Appendix A exhibited the outcomes of summarized CFA for the considered factors and indicators that demonstrated the considered factors and indicators followed the cut-offs, such as Parsimonious fit indices (PCFI $>0.75$, PGFI $>0.75$ and PNFI $>0.75$ ), absolute fit indices (GFI $>0.95, \chi^{2}$-low, probability $<0.05, \chi^{2} / \mathrm{df}$-relative $\chi^{2}<5.0$ ), relative fit-indices (NFI $>0.90$, IFI $>0.95$, TLI $>0.95$ ), and Non-centrality based fit indices (RNI $>0.95$, CFI $>$ 0.95 and RMSEA $<0.05)$ that specifies the good model fitness [154-156].

\subsection{Hypothesized Relationship of Direct Impact}

The outcomes of Table 4 demonstrated the hypothesized association between the independent and dependent variables. The researchers have formulated four hypotheses to examine the influence of email marketing, mobile phone marketing, SEO and companies' websites marketing, and social media marketing on the effectiveness of online digital media marketing for building brand sustainability. Fur hypotheses $(\mathrm{H} 1-\mathrm{H} 4)$ have been formulated for this purpose, the outcomes demonstrated that the email marketing, mobile phone marketing, search engine optimization and companies websites marketing, and social media marketing have a positive and significant influence on the effectiveness of online digital media advertising campaigns ( $\mathrm{T}>2$ and $p<0.05$ ). The individual results demonstrated that mobile phone marketing has the highest influence (0.649), and the least impact (0.115) of social media marketing have been observed on the effectiveness of online digital media advertising (ODA). However, email marketing has an impact (0.223) on ODA, and search engine optimization and companies' websites marketing has an influence of (0.133) on the effectiveness of online digital advertising (ODA) for building brand sustainability. 
Table 4. Standardized regression weights for the research model (predictors on dependent variable).

\begin{tabular}{cccccccc}
\hline Hypothesis & Variables & Regression Paths & $\begin{array}{c}\text { Standardized Regression } \\
\text { Weights }(\boldsymbol{\beta})\end{array}$ & SE & $\mathbf{T}$ & $\mathbf{P}$ & Decision \\
\hline H1 & Email marketing & EM $+\rightarrow$ ODA & 0.223 & 0.030 & 7.347 & 0.000 & Supported \\
\hline H2 & $\begin{array}{c}\text { Mobile phone } \\
\text { marketing }\end{array}$ & MPM $+\rightarrow$ ODA & 0.649 & 0.025 & 25.371 & 0.000 & Supported \\
\hline H3 & $\begin{array}{c}\text { SEO \& CW } \\
\text { marketing }\end{array}$ & $\begin{array}{c}\text { SEO \& CWM }+\rightarrow \\
\text { ODA }\end{array}$ & 0.133 & 0.030 & 4.772 & 0.000 & Supported \\
\hline H4 & $\begin{array}{c}\text { Social media } \\
\text { marketing }\end{array}$ & SMM $+\rightarrow$ ODA & 0.115 & 0.029 & 4.490 & 0.000 & Supported \\
\hline
\end{tabular}

Note: $+=$ Predictor; $\mathrm{DV}=$ ODA = Online digital Advertising; $\mathrm{EM}=$ Email Marketing; $\mathrm{MPM}=$ Mobile Phone Marketing; SEO \& CWM = Search Engines Optimization and Companies' Websites Marketing; SMM = Social Media Marketing.

\subsection{Hypothesized Relationship of Mediation}

The results in Table 5 demonstrated the mediating impact of brand awareness in an association of exogenous variables, such as email marketing and mobile phone marketing, SEO and companies' websites marketing, social media marketing, and endogenous variable i.e., online digital media advertising for building brand sustainability. The results of mediation have been extracted through normal theory and bootstrapping methods. We formulated thirty-two hypotheses of eight sets, such as H5A-H5D, H6A-H6D, H7A-H7D, H8A-H8D, H9A-H9D, H10A-H10D, H11A-H11D, and H12A-H12D. In the bootstrapping method, we analyze the zero between Boot LLCI and Boot ULCI, if zero does not lie between $95 \%$ bias-corrected bootstrapping confidence interval, then we conclude the perfect mediation [157]. Thus, the outcomes of Table 5 exhibited that the all eight mediating variables have significant impact between exogenous variables and the impact of online digital advertising (ODA), except the H9C: SEO \& CW and ODA \& H9D: SMM and ODA, and H11C: SEO \& CW and ODA \& H11D: SMM and ODA. Similar results have been depicted by the normal theory method as $Z> \pm 1.96$, and the corresponding probabilities are less than $0.05[80,155]$. Hence, it is finally concluded that all the sets of hypotheses are supported and confirmed the perfect mediation of all eight mediators between the exogenous and endogenous variables, except H9C, H9D, H11C, and H11D. Thus, both the Bootstrapping and Normal theory methods exhibited that mediating variables, such as characteristics of the advertisement, have a significant and positive influence between email marketing and online digital advertising, mobile phone marketing and online digital adverting, search engine optimization and companies' websites and online digital advertising, and social media marketing and online digital advertising. Similarly, design of the advertisement, duration of the advertisement, and quality of content of advertisement have significant mediating influence between email marketing, and online digital advertising, mobile phone marketing and online digital adverting, search engine optimization and companies' websites and online digital advertising, and social media marketing and online digital advertising. Similarly, customers' attitude has significant mediating influence between email marketing and online digital advertising, and mobile phone marketing and online digital advertising. The mediator brand loyalty also has significant influence between email marketing and online digital advertising, mobile phone marketing, and online digital adverting, search engine optimization and companies' websites and online digital advertising, and social media marketing and online digital advertising. Likewise, the mediator previous purchase experience also has significant influence between email marketing and online digital advertising, and mobile phone marketing and online digital advertising. Finally, word of mouth has a significant influence between EM and ODA, MPM and ODA, SEO \& CW and ODA, and SMM and ODA. 
Table 5. Mediation analysis.

\begin{tabular}{|c|c|c|c|c|c|c|c|c|c|c|}
\hline \multirow{2}{*}{ Hypotheses } & \multirow{2}{*}{ Mediation } & \multicolumn{4}{|c|}{ Bootstrapping Method } & \multicolumn{4}{|c|}{ Normal Theory Method } & \multirow{2}{*}{ Decision } \\
\hline & & Indirect Effect & Boot SE & Boot LLCI & Boot ULCI & Indirect Effect & SE & $\mathrm{Z}^{*}$ & Prob. ** & \\
\hline H5A & $\mathrm{EM} \rightarrow \mathrm{COA} \rightarrow \mathrm{ODA}$ & 0.261 & 0.040 & 0.175 & 0.333 & 0.261 & 0.041 & 6.308 & 0.000 & Supported \\
\hline H5B & $\mathrm{MPM} \rightarrow \mathrm{COA} \rightarrow \mathrm{ODA}$ & 0.269 & 0.033 & 0.203 & 0.335 & 0.269 & 0.033 & 8.102 & 0.000 & Supported \\
\hline $\mathrm{H} 5 \mathrm{C}$ & $\mathrm{SEOCW} \rightarrow \mathrm{COA} \rightarrow \mathrm{ODA}$ & 0.305 & 0.044 & 0.211 & 0.387 & 0.305 & 0.045 & 6.793 & 0.000 & Supported \\
\hline H5D & $\mathrm{SMM} \rightarrow \mathrm{COA} \rightarrow \mathrm{ODA}$ & 0.272 & 0.036 & 0.199 & 0.342 & 0.272 & 0.036 & 7.443 & 0.000 & Supported \\
\hline H6A & $\mathrm{EM} \rightarrow \mathrm{DSA} \rightarrow \mathrm{ODA}$ & 0.248 & 0.039 & 0.182 & 0.334 & 0.248 & 0.039 & 6.324 & 0.000 & Supported \\
\hline H6B & $\mathrm{MPM} \rightarrow \mathrm{DSA} \rightarrow \mathrm{ODA}$ & 0.076 & 0.036 & 0.006 & 0.149 & 0.076 & 0.035 & 2.125 & 0.033 & Supported \\
\hline $\mathrm{H} 6 \mathrm{C}$ & $\mathrm{SEOCW} \rightarrow \mathrm{DSA} \rightarrow \mathrm{ODA}$ & 0.193 & 0.038 & 0.123 & 0.275 & 0.193 & 0.038 & 5.072 & 0.000 & Supported \\
\hline H6D & $\mathrm{SMM} \rightarrow \mathrm{DSA} \rightarrow \mathrm{ODA}$ & 0.178 & 0.033 & 0.116 & 0.249 & 0.178 & 0.033 & 5.372 & 0.000 & Supported \\
\hline H7A & $\mathrm{EM} \rightarrow \mathrm{DUA} \rightarrow \mathrm{ODA}$ & 0.391 & 0.033 & 0.324 & 0.456 & 0.391 & 0.033 & 11.802 & 0.000 & Supported \\
\hline H7B & $\mathrm{MPM} \rightarrow \mathrm{DUA} \rightarrow \mathrm{ODA}$ & 0.285 & 0.039 & 0.204 & 0.361 & 0.285 & 0.040 & 7.091 & 0.000 & Supported \\
\hline $\mathrm{H} 7 \mathrm{C}$ & $\mathrm{SEOCW} \rightarrow \mathrm{DUA} \rightarrow \mathrm{ODA}$ & 0.353 & 0.036 & 0.283 & 0.422 & 0.353 & 0.036 & 9.765 & 0.000 & Supported \\
\hline H7D & $\mathrm{SMM} \rightarrow \mathrm{DUA} \rightarrow \mathrm{ODA}$ & 0.340 & 0.034 & 0.275 & 0.408 & 0.340 & 0.034 & 9.796 & 0.000 & Supported \\
\hline $\mathrm{H} 8 \mathrm{~A}$ & $\mathrm{EM} \rightarrow \mathrm{QCA} \rightarrow \mathrm{ODA}$ & -0.362 & 0.057 & -0.495 & -0.272 & -0.362 & 0.055 & -6.512 & 0.000 & Supported \\
\hline H8B & $\mathrm{MPM} \rightarrow \mathrm{QCA} \rightarrow \mathrm{ODA}$ & -0.108 & 0.035 & -0.181 & -0.043 & -0.108 & 0.034 & -3.100 & 0.001 & Supported \\
\hline $\mathrm{H} 8 \mathrm{C}$ & $\mathrm{SEOCW} \rightarrow \mathrm{QCA} \rightarrow \mathrm{ODA}$ & -0.226 & 0.049 & -0.335 & -0.137 & -0.226 & 0.050 & -4.522 & 0.000 & Supported \\
\hline H8D & $\mathrm{SMM} \rightarrow \mathrm{QCA} \rightarrow \mathrm{ODA}$ & -0.204 & 0.035 & -0.282 & -0.142 & -0.204 & 0.034 & -5.856 & 0.000 & Supported \\
\hline H9A & $\mathrm{EM} \rightarrow \mathrm{CA} \rightarrow \mathrm{ODA}$ & -0.062 & 0.029 & -0.118 & -0.005 & -0.062 & 0.029 & -2.122 & 0.033 & Supported \\
\hline H9B & $\mathrm{MPM} \rightarrow \mathrm{CA} \rightarrow \mathrm{ODA}$ & -0.073 & 0.027 & -0.127 & -0.020 & -0.073 & 0.027 & -2.638 & 0.008 & Supported \\
\hline $\mathrm{H} 9 \mathrm{C}$ & $\mathrm{SEOCW} \rightarrow \mathrm{CA} \rightarrow \mathrm{ODA}$ & -0.018 & 0.026 & -0.069 & 0.035 & -0.018 & 0.026 & -0.713 & 0.475 & Not Supported \\
\hline H9D & $\mathrm{SMM} \rightarrow \mathrm{CA} \rightarrow \mathrm{ODA}$ & -0.017 & 0.042 & -0.099 & 0.063 & -0.017 & 0.042 & -0.414 & 0.678 & Not Supported \\
\hline $\mathrm{H} 10 \mathrm{~A}$ & $\mathrm{EM} \rightarrow \mathrm{BLO} \rightarrow \mathrm{ODA}$ & -0.186 & 0.047 & -0.285 & -0.096 & -0.186 & 0.048 & -3.838 & 0.000 & Supported \\
\hline H10B & $\mathrm{MPM} \rightarrow \mathrm{BLO} \rightarrow \mathrm{ODA}$ & -0.108 & 0.043 & -0.191 & -0.022 & -0.108 & 0.043 & -2.464 & 0.013 & Supported \\
\hline $\mathrm{H} 10 \mathrm{C}$ & $\mathrm{SEOCW} \rightarrow \mathrm{BLO} \rightarrow \mathrm{ODA}$ & -0.128 & 0.044 & -0.212 & -0.039 & -0.128 & 0.045 & -2.846 & 0.004 & Supported \\
\hline H10D & $\mathrm{SMM} \rightarrow \mathrm{BLO} \rightarrow \mathrm{ODA}$ & -0.116 & 0.045 & -0.205 & -0.026 & -0.116 & 0.045 & -2.540 & 0.011 & Supported \\
\hline H11A & $\mathrm{EM} \rightarrow \mathrm{PPE} \rightarrow \mathrm{ODA}$ & -0.095 & 0.033 & -0.160 & -0.035 & -0.095 & 0.031 & -2.991 & 0.002 & Supported \\
\hline H11B & $\mathrm{MPM} \rightarrow \mathrm{PPE} \rightarrow \mathrm{ODA}$ & -0.073 & 0.033 & -0.140 & -0.009 & -0.073 & 0.033 & -2.185 & 0.0289 & Supported \\
\hline $\mathrm{H} 11 \mathrm{C}$ & $\mathrm{SEOCW} \rightarrow \mathrm{PPE} \rightarrow \mathrm{ODA}$ & -0.073 & 0.039 & -0.155 & 0.000 & -0.073 & 0.039 & -1.859 & 0.063 & Not Supported \\
\hline H11D & $\mathrm{SMM} \rightarrow \mathrm{PPE} \rightarrow \mathrm{ODA}$ & -0.067 & 0.038 & -0.145 & 0.006 & -0.067 & 0.039 & -1.734 & 0.082 & Not Supported \\
\hline $\mathrm{H} 12 \mathrm{~A}$ & $\mathrm{EM} \rightarrow \mathrm{WOM} \rightarrow \mathrm{ODA}$ & -0.095 & 0.033 & -0.160 & -0.035 & 0.433 & 0.033 & 12.902 & 0.000 & Supported \\
\hline H12B & $\mathrm{MPM} \rightarrow \mathrm{WOM} \rightarrow \mathrm{ODA}$ & 0.393 & 0.028 & 0.341 & 0.452 & 0.393 & 0.029 & 13.389 & 0.000 & Supported \\
\hline $\mathrm{H} 12 \mathrm{C}$ & $\mathrm{SEOCW} \rightarrow \mathrm{WOM} \rightarrow \mathrm{ODA}$ & 0.456 & 0.030 & 0.403 & 0.525 & 0.456 & 0.031 & 14.564 & 0.000 & Supported \\
\hline $\mathrm{H} 12 \mathrm{D}$ & $\mathrm{SMM} \rightarrow \mathrm{WOM} \rightarrow \mathrm{ODA}$ & 0.425 & 0.029 & 0.375 & 0.491 & 0.425 & 0.028 & 14.886 & 0.000 & Supported \\
\hline
\end{tabular}

* denotes the values of $Z>1.96$ and $Z>-1.96$; ${ }^{* *}$ denotes $p<0.05$; Note: ODA = Online digital advertising; EM = Email marketing; MPM = Mobile phone marketing; SCWM = Search engine optimization and companies' websites marketing; SMM = Social media marketing; COA = Characteristics of advertising; DSA = Design of advertising; DUA = Duration of advertising; $\mathrm{QCA}=$ Quality content advertising; $\mathrm{CA}=$ Customer attitude; $\mathrm{PPE}=$ Previous purchase experience; WOM = Word of mouth. 


\subsection{Hypothesized Relationship of Moderation}

The results of Table 6 have shown that all of the moderating variables, such as innovation in information technology, fiber optics Internet, speed of processors, innovation in telecommunication technology, smartphone, and generation technologies (1G-5G) have significant effect between the exogenous variables, such as: email marketing, mobile phone marketing, SEO and companies' websites marketing, and social media marketing, and online digital advertising (endogenous variable) for building brand sustainability, except the moderation of fiber optics Internet between social media marketing and online digital media advertising. The values of T-statistics are greater than 2 , and the corresponding probabilities are less than $0.000(p<0.000)$; hence, this confirmed the significant influence of moderation of all the variables between exogenous variables, and online digital advertising (dependent variable) for building brand sustainability, except the moderation of fiber optics Internet between social media marketing and online digital media advertising.

Table 6. Moderating effect.

\begin{tabular}{|c|c|c|c|c|c|c|c|c|c|}
\hline Hypotheses & Moderator & Moderation & Coefficient & SE & $\mathbf{T}$ & $p^{*}$ & LLCI & ULCI & Decision \\
\hline \multicolumn{10}{|c|}{ Moderating Effect of IIT b/w EM and ODA } \\
\hline H13A & IIT & EM x IIT & -0.2173 & 0.0120 & -18.06 & 0.0000 & -0.2409 & -0.1937 & Supported \\
\hline \multicolumn{10}{|c|}{ Moderating Effect of FOI b/w EM and ODA } \\
\hline H14A & FOI & EM $\times$ FOI & -0.0332 & 0.0086 & -3.87 & 0.0000 & -0.0500 & -0.0164 & Supported \\
\hline \multicolumn{10}{|c|}{ Moderating Effect of SOP b/w EM and ODA } \\
\hline H15A & SOP & $\mathrm{EM} \times \mathrm{SOP}$ & -0.2323 & 0.0122 & -19.02 & 0.0000 & -0.2563 & -0.2084 & Supported \\
\hline \multicolumn{10}{|c|}{ Moderating Effect of ITT b/w EM and ODA } \\
\hline H16A & ITT & EM x ITT & -0.1733 & 0.0124 & -13.98 & 0.0000 & -0.1977 & -0.1490 & Supported \\
\hline \multicolumn{10}{|c|}{ Moderating Effect of SMP b/w EM and ODA } \\
\hline H17A & SMP & $\mathrm{EM} \times \mathrm{SMP}$ & -0.1941 & 0.0115 & 16.82 & 0.0000 & -0.2167 & -0.1714 & Supported \\
\hline \multicolumn{10}{|c|}{ Moderating Effect of GTT b/w EM and ODA } \\
\hline H18A & GTT & EM x GTT & -0.0419 & 0.0119 & -3.51 & 0.0000 & -0.0654 & -0.0185 & Supported \\
\hline \multicolumn{10}{|c|}{ Moderating Effect of IIT b/w MPM and ODA } \\
\hline H13B & IIT & MPM x IIT & -0.0687 & 0.0107 & -6.4255 & 0.0000 & -0.0897 & -0.0477 & Supported \\
\hline \multicolumn{10}{|c|}{ Moderating Effect of FOI b/w MPM and ODA } \\
\hline H14B & FOI & MPM x FOI & -0.0212 & 0.0072 & -2.9204 & 0.0036 & -0.0354 & -0.0069 & Supported \\
\hline \multicolumn{10}{|c|}{ Moderating Effect of SOP b/w MPM and ODA } \\
\hline H15B & SOP & MPM x SOP & -0.1233 & 0.0113 & -10.9348 & 0.0000 & -0.1455 & -0.1012 & Supported \\
\hline \multicolumn{10}{|c|}{ Moderating Effect of ITT b/w MPM and ODA } \\
\hline H16B & ITT & MPM x ITT & -0.1071 & 0.0100 & -10.7143 & 0.0000 & -0.1267 & -0.0875 & Supported \\
\hline \multicolumn{10}{|c|}{ Moderating Effect of SMP b/w MPM and ODA } \\
\hline H17B & SMP & $\mathrm{MPM} \times \mathrm{SMP}$ & -0.0643 & 0.0105 & -6.1002 & 0.0000 & -0.0849 & -0.0436 & Supported \\
\hline \multicolumn{10}{|c|}{ Moderating Effect of GTT b/w MPM and ODA } \\
\hline H18B & GTT & MPM x GTT & -0.0557 & 0.0087 & -6.4227 & 0.0000 & -0.0728 & -0.0387 & Supported \\
\hline \multicolumn{10}{|c|}{ Moderating Effect of IIT b/w SEOCW and ODA } \\
\hline $\mathrm{H} 13 \mathrm{C}$ & IIT & SEOCW x IIT & -0.1516 & 0.0125 & -12.1523 & 0.0000 & -0.1761 & -0.1272 & Supported \\
\hline \multicolumn{10}{|c|}{ Moderating Effect of FOI b/w SEOCW and ODA } \\
\hline $\mathrm{H} 14 \mathrm{C}$ & FOI & SEOCW $x$ FOI & -0.0612 & 0.0093 & -6.6096 & 0.0000 & -0.0793 & -0.0430 & Supported \\
\hline \multicolumn{10}{|c|}{ Moderating Effect of SOP b/w SEOCW and ODA } \\
\hline H15C & SOP & SEOCW x SOP & -0.1534 & 0.0134 & -11.4289 & 0.0000 & -0.1798 & -0.1271 & Supported \\
\hline \multicolumn{10}{|c|}{ Moderating Effect of ITT b/w SEOCW and ODA } \\
\hline H16C & ITT & SEOCW x ITT & -0.1466 & 0.0127 & -11.5462 & 0.0000 & -0.1716 & -0.1217 & Supported \\
\hline \multicolumn{10}{|c|}{ Moderating Effect of SMP b/w SEOCW and ODA } \\
\hline $\mathrm{H} 17 \mathrm{C}$ & SMP & SEOCW $\times$ SMP & -0.1291 & 0.0122 & -10.6272 & 0.0000 & -0.1530 & -0.1053 & Supported \\
\hline \multicolumn{10}{|c|}{ Moderating Effect of GTT b/w SEOCW and ODA } \\
\hline $\mathrm{H} 18 \mathrm{C}$ & GTT & SEOCW x GTT & -0.0513 & 0.0115 & -4.4831 & 0.0000 & -0.0738 & -0.0289 & Supported \\
\hline
\end{tabular}


Table 6. Cont.

\begin{tabular}{|c|c|c|c|c|c|c|c|c|c|}
\hline Hypotheses & Moderator & Moderation & Coefficient & SE & $\mathrm{T}$ & $p^{*}$ & LLCI & ULCI & Decision \\
\hline \multicolumn{10}{|c|}{ Moderating Effect of IIT b/w SMM and ODA } \\
\hline H13D & IIT & SMM x IIT & -0.1675 & 0.0118 & -14.1478 & 0.0000 & -0.1907 & -0.1442 & Supported \\
\hline \multicolumn{10}{|c|}{ Moderating Effect of FOI b/w SMM and ODA } \\
\hline H14D & FOI & SMM x FOI & -0.0042 & 0.0081 & -0.5212 & 0.6024 & -0.0202 & -0.0117 & Not Supported \\
\hline \multicolumn{10}{|c|}{ Moderating Effect of SOP b/w SMM and ODA } \\
\hline H15D & SOP & SMM $\times$ SOP & -0.1946 & 0.0119 & -16.3033 & 0.0000 & -0.2180 & -0.1712 & Supported \\
\hline \multicolumn{10}{|c|}{ Moderating Effect of ITT b/w SMM and ODA } \\
\hline H16D & ITT & SMM x ITT & -0.1203 & 0.0119 & -10.0857 & 0.0000 & -0.1437 & -0.0969 & Supported \\
\hline \multicolumn{10}{|c|}{ Moderating Effect of SMP b/w SMM and ODA } \\
\hline H17D & SMP & SMM $\times$ SMP & -0.1620 & 0.0115 & -14.1348 & 0.0000 & -0.1845 & -0.1395 & Supported \\
\hline \multicolumn{10}{|c|}{ Moderating Effect of GTT b/w SMM and ODA } \\
\hline H18D & GTT & SMM $\times$ GTT & -0.0770 & 0.0104 & -7.4359 & 0.0000 & -0.0973 & -0.0567 & Supported \\
\hline
\end{tabular}

\subsubsection{Conditional Effect of Moderators}

According to Hayes [147] and Ahmed et al. [11], the different quantitative readings are $\pm 1 S D$ from the mean value that parallels to the 25th, 50th, and 75th percentile of the distribution of moderating variables' scale in the sample at the $95 \%$ confidence interval. The outcomes exhibited that the conditional effect of the exogenous variables, including email marketing, mobile phone marketing, and social media marketing on the effectiveness of online digital media advertising for building brand sustainability at three values the moderating variables, such as: innovation in information technology, fiber optics Internet, speed of processors, innovation in telecommunication technology, smartphone, and generation $(1 \mathrm{G}-5 \mathrm{G})$ technologies are significant, because the corresponding probabilities i.e., $p<0.05[11,157]$.

\subsubsection{Visualization of the Conditional Effect}

Researchers produced 3D Plots to observe the interaction of moderating variables, such as: innovation in information technology, fiber optics Internet, speed of processors, innovation in telecommunication technology, smartphones, and generations (1G-5G) technologies, and exogenous variables, such as email marketing, mobile phone marketing, search engine optimization and companies' websites marketing, and social media marketing, and visualize the effectiveness of online digital media advertising, as displayed in Figure A2 in Appendix A. The 3D plots show that exogenous variables and the effectiveness of online digital media advertising felt a significant influence, while researchers assimilated the moderating variables. The values of online digital media advertising are changing with the variations of moderating variables' values. This is an essential condition to show the graphical plotting of moderating influence, because it explains the conclusive evidence of moderation between exogenous and endogenous variables [11,157]. According to 3D plots, the purple color depicts the effects of moderating variables, the red color portrays the exogenous variables' readings, and the orange color illustrated the effectiveness of online digital media advertising. Hence, from the 3D plots it is concluded that all of the moderating variables have significant influence in a relationship of exogenous variables, and online digital media advertising for building brand sustainability, because, at every reading of moderating variables, the readings of effectiveness of interactive digital media channels advertising changes, and kept on changing with the variation of moderating variables' values. Only one hypothesis H14D regarding the moderating influence of fiber optics Internet between social media marketing and online digital media advertising has not been substantiated, otherwise, all the sets of hypotheses, such as H13A-H13D, H14A-H14C, H15A-H15D, H16A-H16D, H17A-H17D, and H18A-H18D, have been supported and confirmed the influence of the moderating variables. 


\section{Discussions}

The outcomes of the undertaken study demonstrated that the channels of online digital media have positive and significant influence on the effectiveness of online digital media advertising for building brand sustainability. The mobile phone marketing tool has the most cogent influence, and these results are consistent with previous literature [139-142], and then email marketing channel has a significant positive influence on the online digital media advertising, these results are in line with previous research studies, such as Lee et al. [30] and Yoon [103], and are followed by SEO and companies' websites marketing tools, and these results are also consistent with the previous literature $[35,36,38,74]$. However, the previous research studies concluded the email marketing is an effective communication tool, but these studies have been carried out in perspective of business-to-business marketing, where email marketing plays a vital role when compared to any other online media channel. On the contrary, we have used email tools for both B2B and B2C business, and our respondents were mixed; therefore, our results are bit different from few previous research studies. Moreover, a search engine optimization tool has also played an important and vibrant role in western populations while they complete online purchases $[11,49,75]$, but in the Pakistani context, people are not mainly using search engines for the online purchases, rather they use other channels, such as mobile marketing, and social media marketing etc. $[79,80]$. Interestingly, the mobile marketing channels are more effective in the case of Pakistan, whereas, in the Western studies, the social media is the most powerful tool $[49,68,71]$, but several previous research studies substantiated the similar results, where mobile phone marketing plays a significant role, such as in [85-87]. Another important factor for the popularity of mobile phone marketing is smartphone usage by the new generation, which are more actively involved in online purchases in Pakistan. The researchers have also examined the impact of characteristics of online advertisement, design of advertisement, duration of advertisement, quality content of advertisement as mediating variables between exogenous variables and endogenous variable, and the results of the mediating effect demonstrated a significant influence, which further substantiated the previous studies [101-104]; the significance of these factors demonstrated how important these elements are for the digital marketers while constructing online advertising messages. Moreover, the researchers have introduced customers' attitude, previous purchase experience, brand loyalty, and word of mouth as the mediating variables and concluded the significant influence of these mediating variables between the exogenous variables and endogenous variable, which is also in line with previous literature $[80,105,108,110]$, thus these results further demonstrated that digital marketers should also take care of the psychological and behavioral factors of the consumers while making any digital advertisement. Thus, the overall outcomes are coherent with the previous literature, which demonstrated the same positive and significant impact of customers' attitude and word of mouth $[106,107,109]$; brand loyalty and sustainability are also consistent with the previous literature, such as $[105,120,125,137]$, and previous purchase experience is also very much in line with the previous literature e.g., [30,80]. Technology always remained a vital factor in digital media communication tools, as indicated by previous researchers $[50,80,130]$; therefore, the researchers have incorporated innovations in information technology, fiber optics Internet, and speed of processors as moderating variables, and concluded the significant moderating effect of these variables, which further enhance the effectiveness of online digital advertising in relation to exogenous variables. Thus, these outcomes have substantiated the previous literature that also demonstrated similar results $[47,51,75,133,134]$. The researchers have further incorporated innovations in telecommunication, smartphones, and generation $(1 \mathrm{G}-5 \mathrm{G})$ telecommunications as the moderating variables and concluded the same significant influence of these moderating variables between the exogenous variables, and the effectiveness of online digital media for building brand sustainability. The research results are also coherent with the results of previous literature $[11,25,28,143]$. The outcomes of technological elements are the most important for online digital media advertising, because the technology is changing in hours, not in weeks or months; therefore, for the effective, fastest, and customized advertising, it is essential to embed all kinds of new technologies, as examined in the undertaken study should be taken care. 


\section{Conclusions}

This research is a comprehensive study, which was conducted in Pakistan to date, pertaining to the role of online digital media channels to establish the effectiveness of online digital media advertising for building brand sustainability. This research covers the services sector and manufacturing sector of Pakistani industry, and researchers have taken those organizations, which are effectively involved in online digital media advertising and successfully while using all of these online digital media channels for the online advertising for their brands. The outcomes of the undertaken study concluded that the channels of online digital media have a positive and significant influence on the effectiveness of online digital media advertising for building brand sustainability. The mobile phone marketing tool has the most cogent influence, and then the email marketing channel, and followed by the SEO \& companies' websites marketing tool. Interestingly, the mobile marketing channels are more effective in the case of Pakistan, whereas, in Western studies, social media is the most powerful tool. The reasons behind these findings are the cost-effectiveness of the mobile phone SMS, and the availability of databases of the consumers, and, most importantly, the lack of implementation of existing legislation and laws for using the protection of consumers' data. The outcomes of hypotheses pertaining to the mediating effect of different variables, such as: characteristics of the online advertisement, design of advertisement, duration of advertisement, quality contents of advertisement, consumers' attitude, brand loyalty, previous purchase experience, and word of mouth between exogenous variables and the effectiveness of online digital media advertising have substantiated the positive and significant effect between the exogenous variables and dependent variable, except for the mediation of customer attitude and previous purchase experience between SEO and companies' websites marketing, and the endogenous variable, and mediation customers' attitude, and previous purchase experience between social media marketing and the effectiveness of online digital media advertising. Thus, this further concluded that there are several factors, which are important in creating an online advertisement, thus, the marketer should take these mediating variables while devising any integrated marketing communication (IMC) campaign for online digital media for the optimal outcomes. Similarly, the outcomes of hypotheses pertaining to the moderating effect of different variables, such as: innovations in information technology, fiber optics Internet, speed of processors, innovations in telecommunication technology, smartphone, and generations $(1 \mathrm{G}-5 \mathrm{G})$ telecommunication technologies between the exogenous variables and the effectiveness of online digital media advertising have substantiated the significant effect between exogenous variables and dependent variable, except the moderation of fiber optics Internet between social media marketing and creativity and effectiveness of online digital media advertising. Hence, it is proved that the technology is the most significant factor for devising online digital advertising, the technology is changing in hours, not weeks or months, and thus digital marketers should be more vigilant to adopt diverse elements of latest technologies in order to gain a competitive advantage. The overall results concluded that the online digital media tools have significant and positive influence on the effectiveness of online digital advertising, thus, it is also demonstrated that the sustainability of interactive digital media has a major factor for the long term brand awareness, brand recall, brand loyalty, and building brand sustainability for manufacturing and services sectors of Pakistani industry. It is further concluded that the considered moderating and mediating variables have cogent influence between the exogenous and endogenous variables that further enhance the brand sustainability and repeat purchase. It is finally concluded that the sustainability of online digital media channels and sustainability of mediating and moderating variables also brought significant positive influence on brands' recall, brand life, and augmented business opportunities as compared to the competitors.

\subsection{The Managerial and Theoretical Contribution}

The results of this research have provided the basic foil to the policymakers of the organizations to set their right directions, while they take the strategic decisions for making advertising and sales promotion strategies for their valuable brands. This research is a valuable guide to the brand managers, marketing managers, digital media managers, and advertisers of professional agencies that are intensely 
involved in offering their services to individuals and organizations. Moreover, the results of this research have provided directions to government agencies, which are involved in making rules and regulations, and law enforcement to protect the consumers' rights. The brand managers, marketing managers, advertisers, and digital media managers should adopt the online media channels as the first line of advertisement and sales promotion due to cost-effectiveness, global reach, real-time interactivity to the consumers and customers, high response rate, instant feedback, and excellent customer relationship. The brand managers and the digital media managers should get the comprehensive customers data from the cellular companies or they make them a partner in the business to launch more effective online advertising campaigns to capture the largest customers' pool. The brand managers and digital media managers should allocate more emphasis to the design of an advertisement, effective and quality content of the advertisement, while they devise and craft the online advertisement. Moreover, the timing or duration of online advertisement also played a significant influence as a mediating variable; therefore, the brand managers and digital media managers should take care the right slot, timing, and duration when they do advertise their advertisement campaigns on the online digital media channels. This study also recommends to the brand managers and digital media managers to obtain the greatest benefits of these technologies in their online advertising campaigns and create their ads, which will be user-friendly and support these technologies. Finally, it is recommended to the relevant government agencies to intervene for the online consumers' rights and provide a safe and secure online shopping environment to the Pakistani online consumers.

\subsection{Limitations and Suggested Areas of Future Research}

The potential area of future research is the comparative analysis with other regional countries, such as India, China, Bangladesh, Iran, and other South Asian countries. This research is based on the Pakistani perspective; thus, more generalized results could be concluded by taking these regional countries. The researchers have taken a few sectors of the economy; therefore, future research might be focused on all of the sectors of the Pakistani economy to obtain a comprehensive picture of online digital advertising effectiveness. In undertaken research only four online media channels have been incorporated, thus, it is recommended to future researchers that they should incorporate the remaining online media channels for their research studies. This research has taken eight mediating variables, however there are numbers of other important mediating variables. Therefore, it is recommended to the future scholars that they should incorporate other important mediating variables for more comprehensive effects of mediation. Finally, the undertaken research has incorporated six important moderating variables, but still, there are numerous other moderating variables that may be taken as the moderating variables for future research studies.

Supplementary Materials: The following are available online at http://www.mdpi.com/2071-1050/11/12/3436/s1, File S1: Questionnaire: Effectiveness of online digital media advertising as a strategic tool for building brand sustainability: Evidence from FMCGs and Services sectors of Pakistan.

Author Contributions: Conceptualization, R.R.A.; Data curation, R.H.S.; Formal analysis, D.S.; Investigation, D.S.; Methodology, R.R.A.; Project administration, Z.A.C.; Resources, D.S.; Software, G.B. and R.H.S.; Supervision, J.V. and Z.A.C.; Validation, Z.A.C.; Visualization, R.R.A. and G.B.; Writing - review \& editing, J.V. All authors contributed equally to this work.

Funding: This research received no external funding.

Conflicts of Interest: The authors declare no conflicts of interest. 


\section{Appendix A}

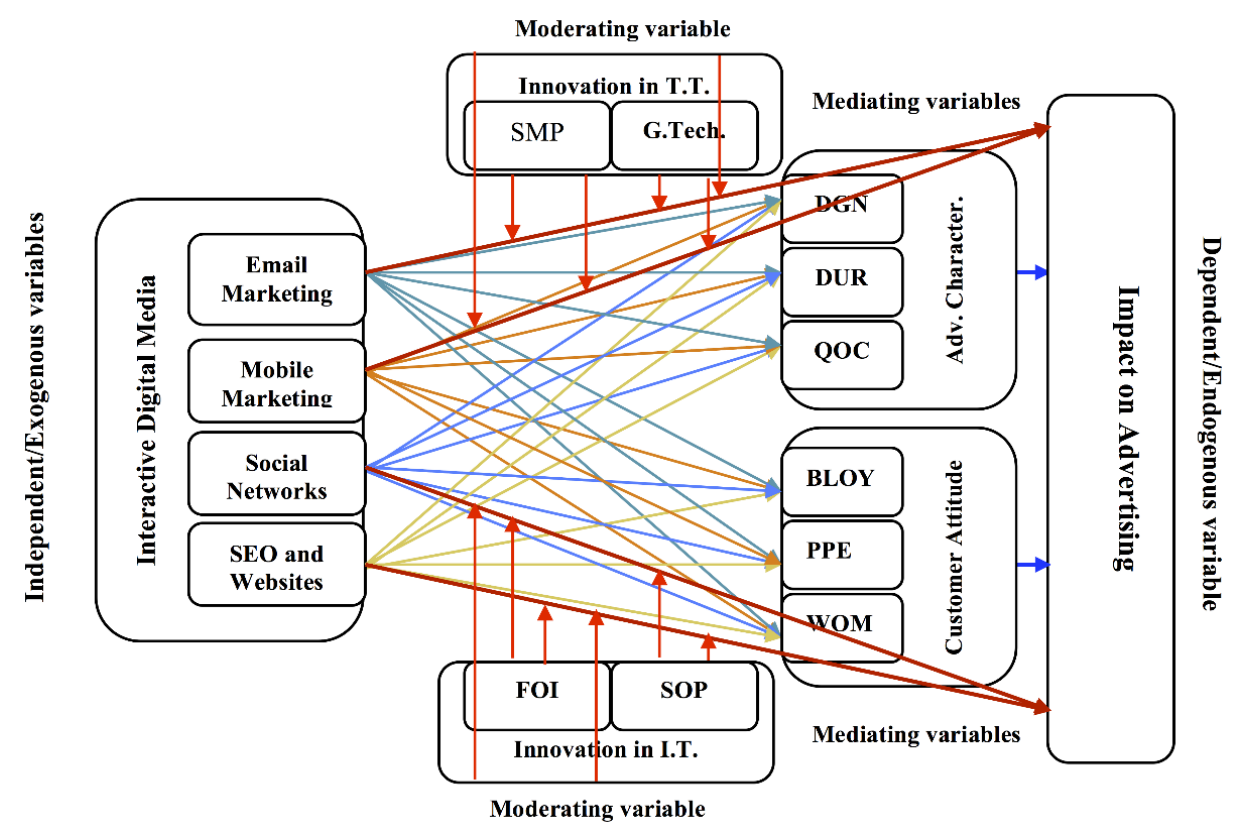

Figure A1. The conceptualized framework of Research Model. 
Table A1. Rotated Component Matrix a (Principal Components Analysis).

\begin{tabular}{|c|c|c|c|c|c|c|c|c|c|c|c|c|c|c|c|c|c|c|c|}
\hline \multirow{2}{*}{ Items/Components } & \multicolumn{19}{|c|}{ Component } \\
\hline & ODA & EM & MPM & SEO \& CWM & SMM & $\mathrm{COA}$ & DSA & DUA & QCA & CA & BLO & PPE & WOM & IIT & FOI & SOP & ITT & SMP & GTT \\
\hline ODA1 & 0.837 & & & & & & & & & & & & & & & & & & \\
\hline ODA2 & 0.736 & & & & & & & & & & & & & & & & & & \\
\hline ODA3 & 0.881 & & & & & & & & & & & & & & & & & & \\
\hline EM1 & & 0.742 & & & & & & & & & & & & & & & & & \\
\hline EM2 & & 0.827 & & & & & & & & & & & & & & & & & \\
\hline EM3 & & 0.805 & & & & & & & & & & & & & & & & & \\
\hline MPM1 & & & 0.842 & & & & & & & & & & & & & & & & \\
\hline MPM2 & & & 0.827 & & & & & & & & & & & & & & & & \\
\hline MPM3 & & & 0.902 & & & & & & & & & & & & & & & & \\
\hline SEOCW1 & & & & 0.842 & & & & & & & & & & & & & & & \\
\hline SEOCW3 & & & & 0.827 & & & & & & & & & & & & & & & \\
\hline SEOCW3 & & & & 0.802 & & & & & & & & & & & & & & & \\
\hline SMM1 & & & & & 0.827 & & & & & & & & & & & & & & \\
\hline SMM2 & & & & & 0.922 & & & & & & & & & & & & & & \\
\hline SMM3 & & & & & 0.798 & & & & & & & & & & & & & & \\
\hline COA1 & & & & & & 0.837 & & & & & & & & & & & & & \\
\hline COA2 & & & & & & 0.728 & & & & & & & & & & & & & \\
\hline $\mathrm{COA} 3$ & & & & & & 0.803 & & & & & & & & & & & & & \\
\hline DSA1 & & & & & & & 0.735 & & & & & & & & & & & & \\
\hline DSA2 & & & & & & & 0.735 & & & & & & & & & & & & \\
\hline DSA3 & & & & & & & 0.806 & & & & & & & & & & & & \\
\hline DUA1 & & & & & & & & 0.749 & & & & & & & & & & & \\
\hline DUA2 & & & & & & & & 0.829 & & & & & & & & & & & \\
\hline DUA3 & & & & & & & & 0.832 & & & & & & & & & & & \\
\hline QCA1 & & & & & & & & & 0.738 & & & & & & & & & & \\
\hline QCA2 & & & & & & & & & 0.831 & & & & & & & & & & \\
\hline QCA3 & & & & & & & & & 0.843 & & & & & & & & & & \\
\hline CA1 & & & & & & & & & & 0.831 & & & & & & & & & \\
\hline CA2 & & & & & & & & & & 0.923 & & & & & & & & & \\
\hline CA3 & & & & & & & & & & 0.797 & & & & & & & & & \\
\hline BLO1 & & & & & & & & & & & 0.841 & & & & & & & & \\
\hline BLO2 & & & & & & & & & & & 0.736 & & & & & & & & \\
\hline BLO3 & & & & & & & & & & & 0.808 & & & & & & & & \\
\hline PPE1 & & & & & & & & & & & & 0.731 & & & & & & & \\
\hline PPE2 & & & & & & & & & & & & 0.838 & & & & & & & \\
\hline PPE3 & & & & & & & & & & & & 0.842 & & & & & & & \\
\hline WOM1 & & & & & & & & & & & & & 0.828 & & & & & & \\
\hline WOM2 & & & & & & & & & & & & & 0.826 & & & & & & \\
\hline WOM3 & & & & & & & & & & & & & 0.902 & & & & & & \\
\hline IIT1 & & & & & & & & & & & & & & 0.728 & & & & & \\
\hline IIT2 & & & & & & & & & & & & & & 0.825 & & & & & \\
\hline IIT3 & & & & & & & & & & & & & & 0.809 & & & & & \\
\hline
\end{tabular}


Table A1. Cont.

\begin{tabular}{|c|c|c|c|c|c|c|c|c|c|c|c|c|c|c|c|c|c|c|c|}
\hline \multirow{2}{*}{ Items/Components } & \multicolumn{19}{|c|}{ Component } \\
\hline & ODA & EM & MPM & SEO \& CWM & SMM & $\mathrm{COA}$ & DSA & DUA & QCA & CA & BLO & PPE & WOM & IIT & FOI & SOP & ITT & SMP & GTT \\
\hline FOI1 & & & & & & & & & & & & & & & 0.728 & & & & \\
\hline FOI2 & & & & & & & & & & & & & & & 0.822 & & & & \\
\hline FOI3 & & & & & & & & & & & & & & & 0.821 & & & & \\
\hline SOP1 & & & & & & & & & & & & & & & & 0.826 & & & \\
\hline SOP2 & & & & & & & & & & & & & & & & 0.921 & & & \\
\hline SOP3 & & & & & & & & & & & & & & & & 0.801 & & & \\
\hline ITT1 & & & & & & & & & & & & & & & & & 0.821 & & \\
\hline ITT2 & & & & & & & & & & & & & & & & & 0.819 & & \\
\hline ITT3 & & & & & & & & & & & & & & & & & 0.834 & & \\
\hline SMP1 & & & & & & & & & & & & & & & & & & 0.829 & \\
\hline SMP2 & & & & & & & & & & & & & & & & & & 0.812 & \\
\hline SMP3 & & & & & & & & & & & & & & & & & & 0.782 & \\
\hline GTT1 & & & & & & & & & & & & & & & & & & & 0.725 \\
\hline GTT2 & & & & & & & & & & & & & & & & & & & 0.816 \\
\hline GTT3 & & & & & & & & & & & & & & & & & & & 0.796 \\
\hline
\end{tabular}

Table A2. Fit-measures of indices for measured and structured models.

\begin{tabular}{|c|c|c|c|c|c|c|c|c|c|c|c|c|c|c|}
\hline \multirow{2}{*}{ Construct } & \multicolumn{5}{|c|}{ Absolute Fit Indices } & \multicolumn{3}{|c|}{ Relative Fit Indices } & \multicolumn{3}{|c|}{ Non-Centrality-Based Indices } & \multicolumn{3}{|c|}{ Parsimonious Fit Indices } \\
\hline & $x^{2}$ & Df & $\mathrm{x}^{2 / \mathrm{df}}$ & Probability & GFI & NFI & IFI & TLI & CFI & RMSEA & RNI & PCFI & PNFI & PGFI \\
\hline Measured model & 4.028 & 1 & 4.028 & 0.028 & 0.969 & 0.950 & 0.970 & 0.951 & 0.970 & 0.032 & 0.952 & 0.757 & 0.825 & 0.798 \\
\hline Structured model & 5.023 & 2 & 2.511 & 0.042 & 0.971 & 0.901 & 0.960 & 0.952 & 0.956 & 0.005 & 0.955 & 0.822 & 0.780 & 0.890 \\
\hline Criteria & Low & N/A & $<5.0$ & $<0.05$ & $>0.95$ & $>0.90$ & $>0.95$ & $>0.95$ & $>0.95$ & $<0.05$ & $>0.95$ & $>0.75$ & $>0.75$ & $>0.75$ \\
\hline
\end{tabular}

Note. $\chi^{2}=$ Chi Square; $\chi^{2} / \mathrm{df}=$ Relative Chi Square; $\mathrm{df}=$ degree of freedom; CFI = Comparative Fit Index; NFI = Normed Fixed Index; IFI = Incremental Fixed Index; TLI = Tucker-Lewis Index; GFI = Goodness of Fit Index; RNI = Relative Non-centrality Index; RMSEA = Root Mean Square Error of Approximation; PNFI = Parsimony-adjusted Normed Fit Index; PCFI =

Parsimony-adjusted Fit Index; PGFI = Parsimony-adjusted Goodness of Fit. 

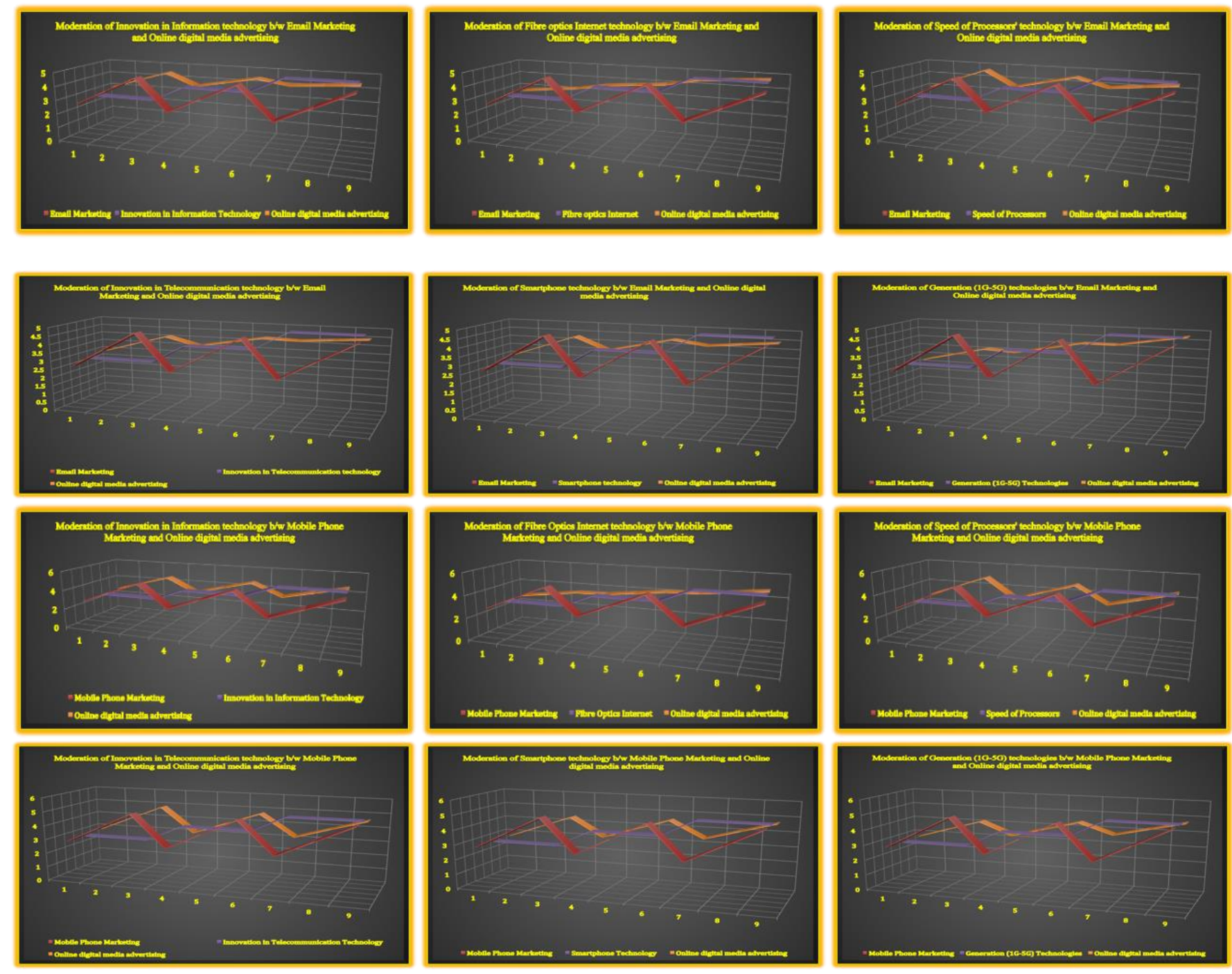

Figure A2. Cont. 

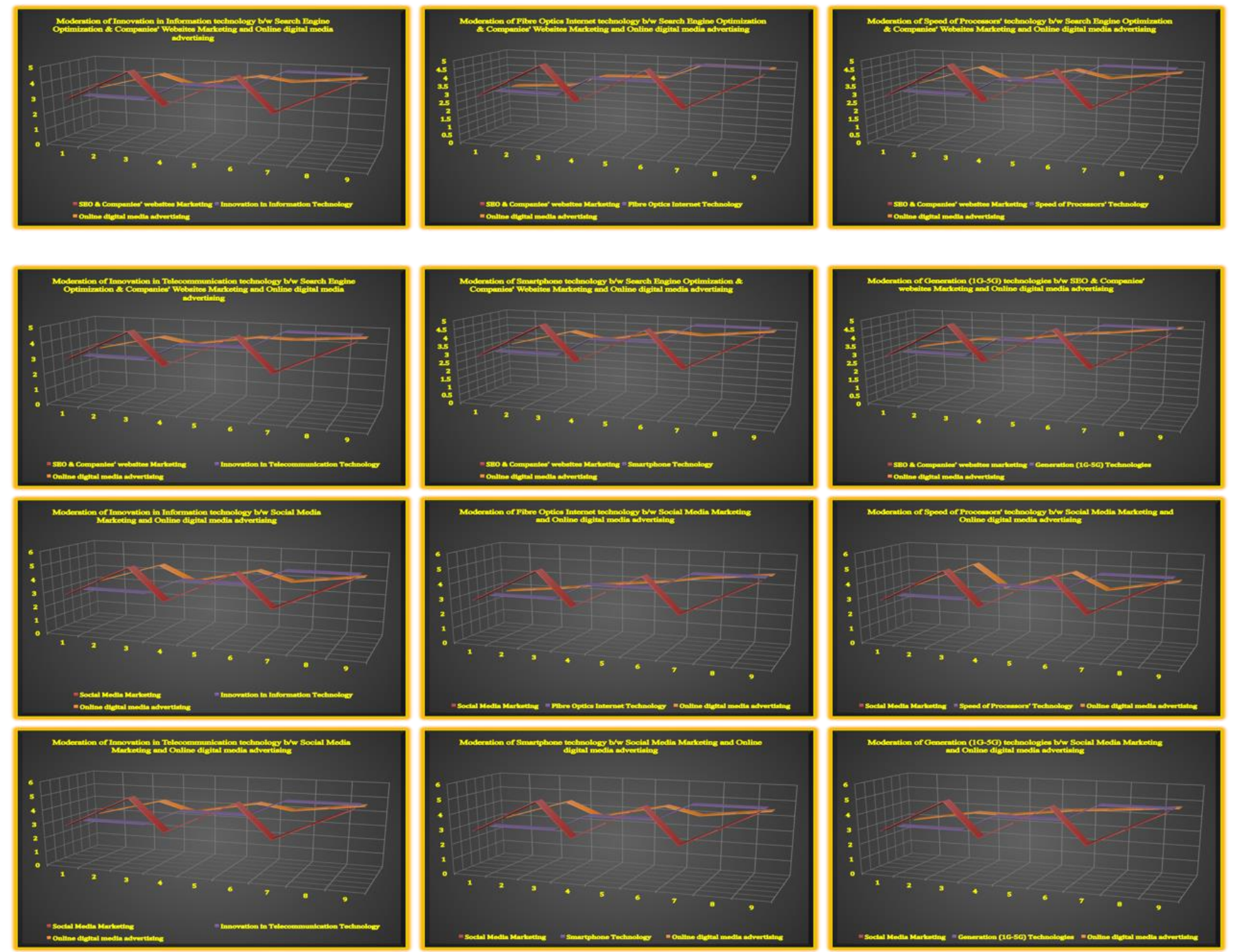

Figure A2. The visualizing conditional effect of moderators. 


\section{References}

1. Deighton, J.A.; Kornfeld, L. Interactivity's Unanticipated Consequences for Marketers and Marketing. J. Interact. Mark. 2009, 23, 2-12. [CrossRef]

2. Bellman, S.; Potter, R.F.; Treleaven-Hassard, S.; Robinson, J.A.; Varan, D. The Effectiveness of Branded Mobile Phone Apps. J. Interact. Mark. 2011, 25, 191-200. [CrossRef]

3. Confos, N.; Davis, T. Young consumer-brand relationship building potential using digital marketing. Eur. J. Mark. 2016, 50, 1993-2017. [CrossRef]

4. Handayanto, A.J. Analysis of Consumer Awareness on Twitter Communication and Brand Equity of Bear Brand Milk. J. Res. Mark. 2016, 5, 348-356. [CrossRef]

5. Mathwick, C.; Wiertz, C.; De Ruyter, K. Social Capital Production in a Virtual P3 Community. J. Consum. Res. 2008, 34, 832-849. [CrossRef]

6. Lee, S.H. Are We Different? Creating the Taxonomy of Digital Media Channels. J. Soc. Media Stud. 2016, 3 , 31-40. [CrossRef]

7. Rossiter, J.R.; Percy, L. Methodological Guidelines for Advertising Research. J. Advert. 2017, 46, 71-82. [CrossRef]

8. Elberse, A. The Reach of Online Movie Trailers. In Proceedings of the Workshop in Motion Picture Industry Studies, Los Angeles, CA, USA, 9 November 2009.

9. Schultz, T. Mass Media and the Concept of Interactivity: An Exploratory Study of Online Forums and Reader E-Mail. Media Cult. Soc. 2000, 22, 205-221. [CrossRef]

10. Ailawadi, K.L.; Lehmann, D.R.; Neslin, S.A. Revenue Premium as an Outcome Measure of Brand Equity. J. Mark. 2003, 67, 1-17. [CrossRef]

11. Ahmed, R.R.; Vveinhardt, J.; Štreimikienè, D.; Ashraf, M. Interactive Digital Media and Impact of Customer Attitude and Technology on Brand Awareness: Evidence from the South Asian Countries. J. Bus. Econ. Manag. 2017, 18, 1115-1134. [CrossRef]

12. Hoyer, W.; Chandy, R.; Dorotic, M.; Krafft, M.; Singh, S. Customer Participation in Value Creation. J. Serv. Res. 2010, 13, 283-296. [CrossRef]

13. Krishnamurthy, S. Mozilla vs. Godzilla-The Launch of the Mozilla Firefox Browser. J. Interact. Mark. 2009, 23, 259-271. [CrossRef]

14. Cathcart, R.; Gumpert, G. Mediated Interpersonal Communication: Toward a New Typology. Q. J. Speech 1983, 69, 267-277. [CrossRef]

15. Massey, B.L.; Levy, M.R. Interactivity, Online Journalism, and English-Language Web Newspapers in Asia. J. Mass Commun. Q. 1999, 76, 138-151. [CrossRef]

16. Ha, L.; James, L. Interactivity Re-Examined: A Baseline Analysis of Early Business Web Sites. J. Broadcast. Electron. Media 1998, 42, 457-474. [CrossRef]

17. Day, G.S. Organizing for Interactivity. J. Interact. Mark. 1998, 12, 47-53. [CrossRef]

18. Lee, J.S. Interactivity: A New Approach. In Proceedings of the Association for Education in Journalism and Mass Communication, Phoenix, AZ, USA, 9-12 August 2000.

19. Reeves, B.; Nass, C. Perceptual Bandwidth'. Commun. ACM 2000, 43, 65-70. [CrossRef]

20. Hoffman, D.L.; Novak, T.P. Marketing in Hypermedia Computer-Mediated Environments: Conceptual Foundations. J. Mark. 1996, 60, 50-68. [CrossRef]

21. Szuprowicz, B.O. Multimedia Networking; McGraw-Hill, Inc.: New York, NY, USA, 1995.

22. Jensen, J.F. Interactivity: Tracing a New Concept in Media and Communication Studies. Nord. Rev. 1998, 19, 185-204.

23. Haeckel, S.H. About the Nature and Future of Interactive Marketing. J. Interact. Mark. 1998, $12,63-71$. [CrossRef]

24. Barker, J.; Tucker, R.N. The Interactive Learning Revolution: Multimedia in Education and Training; Kogan Page: London, UK, 1990.

25. Kayany, J.M.; Wotring, C.E.; Forrest, E.J. Relational Control and Interactive Media Choice in Technology-Mediated Communication Situations. Hum. Commun. Res. 1996, 22, 399-421. [CrossRef]

26. Stromer-Galley, J. Online Interaction and Why Candidates Avoid It. J. Commun. 2000, 50, 111-132. [CrossRef]

27. Chitra, K.; Sasikala, K. Social Media Marketing Strategies for Enhancing Brand Awareness: A Study with reference to select Start-ups. Asian J. Res. Soc. Sci. Humanit. 2016, 6, 1081. [CrossRef] 
28. DeSanctis, G.; Poole, M.S. Capturing the Complexity in Advanced Technology Use: Adaptive Structuration Theory. Organ. Sci. 1994, 5, 121-147. [CrossRef]

29. Winer, R.S. New Communications Approaches in Marketing: Issues and Research Directions. J. Interact. Mark. 2009, 23, 108-117. [CrossRef]

30. Lee, S.S. Walk-through Audit for Enhancing Total Customer Experience: The Case of a Full Service Restaurant. Int. J. Bus. Res. 2010, 10, 141-146.

31. Nuseir, M.T. Exploring the use of Online Marketing Strategies and Digital Media to Improve the Brand Loyalty and Customer Retention. Int. J. Bus. Manag. 2016, 11, 228-239. [CrossRef]

32. Moustakas, E.; Ranganathan, C.; Duquenoy, P. E-mail marketing at the crossroads: A stakeholder analysis of unsolicited commercial e-mail (spam). Internet Res. 2006, 16, 38-52. [CrossRef]

33. Merisavo, M.; Raulas, M. The impact of Email marketing on brand loyalty. J. Prod. Brand Manag. 2004, 13, 498-505. [CrossRef]

34. Malhotra, N.K.; Birks, D.F. Marketing Research—An Applied Approach, 3rd ed.; Pearson Education Ltd.: Essex, UK, 2007.

35. Zhang, X.A.; Kumar, V.; Cosguner, K. Dynamically Managing a Profitable Email Marketing Program. J. Mark. Res. 2017. [CrossRef]

36. Cases, A.S.; Fournier, C.; Dubois, P.L.; Tanner, J.F. Web Site spill over to email campaigns: The role of privacy, trust and shoppers' attitudes. J. Bus. Res. 2010, 63, 993-999. [CrossRef]

37. Mahler, A.; Rogers, E.M. The Diffusion of Interactive Communication Innovations and the Critical Mass: The Adoption of Telecommunication Services by German Banks. Telecommun. Policy 1999, 23, 719-740. [CrossRef]

38. Kim, G.; Shin, B.; Lee, H.G. A study of factors that affect user intentions toward email service switching. Inf. Manag. 2006, 43, 884-893. [CrossRef]

39. Cho, C.H.; Khang, H.K. The state of Internet-related research in communications, marketing, and advertising: 1994-2003. J. Advert. 2006, 35, 143-163. [CrossRef]

40. Kim, J.; McMillan, S.J. Evaluation of Internet Advertising Research: A Bibliometric Analysis of Citations from Key Sources. J. Advert. 2008, 37, 99-112. [CrossRef]

41. Pavlov, O.V.; Melville, N.; Plice, R.K. Toward a sustainable e-mail marketing infrastructure. J. Bus. Res. 2008, 61, 1191-1199. [CrossRef]

42. Filipovic, J. Brand awareness and buying intention in the online environment. Marketing 2015, 46, 277-284. [CrossRef]

43. Geçti, F.; Gümüş, N. Examining the Attitudes towards Mobile Advertising Messages: A Field Research on Turkish Consumers. China-USA Bus. Rev. 2013, 12, 204-210.

44. Radder, L.; Pietersen, J.; Wang, H.; Han, X. Antecedents of South African high school pupils' acceptance of universities' SMS advertising. Int. Bus. Econ. Res. J. 2010, 9, 29-40. [CrossRef]

45. Rafaeli, S.; LaRose, R.J. Electronic Bulletin Boards and "Public Goods" Explanations of Collaborative Mass Media. Commun. Res. 1993, 20, 277-297. [CrossRef]

46. Jenkins, F. Mobile marketing. Young Consum. 2006, 7, 60-63. [CrossRef]

47. Leonard-Barton, D. Implementation as a Mutual Adaptation of Technology and Organization. Res. Policy 1988, 17, 251-268. [CrossRef]

48. Al-Meshal, S.; Almotairi, M. Consumer Acceptance of Mobile Marketing: An Empirical Study on the Saudi Female. Int. J. Mark. Stud. 2013, 5, 94-100. [CrossRef]

49. Çizmeci, F.; Ercan, T. The Effect of Digital Marketing Communication Tools in the Creation of Brand Awareness by Housing Companies. Megaron 2015, 10, 149-161.

50. McCloskey, W. Retail White Paper; Email Data Source: New York, NY, USA, 2006.

51. Muk, A.; Chung, C. Applying the technology acceptance model in a two-country study of SMS advertising. J. Bus. Res. 2015, 68, 1-6. [CrossRef]

52. Xu, D.J.; Liao, S.S.; Li, Q. Combining empirical experimentation and modeling techniques: A design research approach for personalized mobile advertising applications. Decis. Support Syst. 2008, 44, 710-724. [CrossRef]

53. Stewart, D.W.; Pavlou, P.A. From consumer response to active consumer: Measuring the effectiveness of interactive media. J. Acad. Mark. Sci. 2002, 30, 376-396. [CrossRef]

54. Barnes, S.J. Wireless digital advertising: Nature and implications. Int. J. Advert. 2002, 21, 399-420. [CrossRef]

55. Siau, K.; Shen, Z. Building customer trust in mobile commerce. Commun. ACM 2003, 46, 91-94. [CrossRef] 
56. Cao, L.; Liu, X.; Cao, W. The Effects of Search-Related and Purchase-Related Mobile App Additions on Retailers' Shareholder Wealth: The Roles of Firm Size. Product Category, and Customer Segment. J. Retail. 2018, 94, 343-351. [CrossRef]

57. Leppaniemi, M.; Karjaluoto, H. Factors influencing consumer willingness to accept mobile advertising: A conceptual model. Int. J. Mob. Commun. 2005, 3, 197-213. [CrossRef]

58. Rajagopal. Consumer culture and purchase intentions toward fashion apparel in Mexico. J. Database Mark. Cust. Strategy Manag. 2011, 18, 286-307. [CrossRef]

59. Frolick, M.N.; Chen, L.D. Assessing m-commerce opportunities. Inf. Syst. Manag. 2004, 21, 53-61. [CrossRef]

60. Muk, A. Consumers' intention to opt in to SMS advertising. Int. J. Advert. 2007, 26, 177-198. [CrossRef]

61. Kolla, N. Consumer Attitude towards Mobile Advertising: An Empirical Study. Indian J. Appl. Res. 2011, 4, 340-342. [CrossRef]

62. Barwise, P.; Strong, C. Permission-based mobile advertising. J. Interact. Mark. 2002, 16, 14-24. [CrossRef]

63. Bamoriya, P.; Bamoriya, H.; Singh, P. Perceptual mapping of electronic banking channels in India: A Multidimensional Scaling approach. Int. J. Res. Stud. Manag. 2014, 3, 17-26. [CrossRef]

64. Scharl, A.; Dickinger, A.; Murphy, J. Diffusion and success factors of mobile marketing. Electron. Commer. Res. Appl. 2005, 4, 159-173. [CrossRef]

65. Kenny, D.; Marshall, J.F. Contextual marketing: The real business of the Internet. Harv. Bus. Rev. 2000, 78, 119-125.

66. Yuan, S.T.; Tsao, Y.W. A recommendation mechanism for contextualized mobile advertising. Expert Syst. Appl. 2003, 24, 399-414. [CrossRef]

67. Barnes, T. RSS: Marketing newest communication channel. J. Website Promot. 2007, 1, 15-30. [CrossRef]

68. Kaplan, A.M.; Haenlein, M. Users of the world, unite! The challenges and opportunities of social media. Bus. Horiz. 2010, 53, 59-68. [CrossRef]

69. Saura, J.R.; Palos-Sánchez, P.; Cerdá Suárez, L.M. Understanding the digital marketing environment with KPIs and web analytics. Future Internet 2017, 9, 76. [CrossRef]

70. Ross, C.; Orr, E.S.; Sisic, M.; Arseneault, J.M.; Simmering, M.G.; Orr, R.R. Personality and motivations associated with Facebook use. Comput. Hum. Behav. 2009, 25, 578-586. [CrossRef]

71. Hanna, R.; Rohm, A.; Crittenden, V.L. We're all connected: The power of the social media ecosystem. Bus. Horiz. 2011, 54, 265-273. [CrossRef]

72. Kim, H.B.; Kim, W.G.; An, A.J. The effect of consumer based brand equity on firm's financial performance. J. Consum. Mark. 2003, 20, 335-351. [CrossRef]

73. Mohammed, A.B.; Alkubise, M. How Do Online Advertisements Affects Consumer Purchasing Intention: Empirical Evidence from a Developing Country. Eur. J. Bus. Manag. J. 2012, 4, 208-218.

74. Reyes-Menendez, A.; Saura, J.; Palos-Sanchez, P.; Alvarez-Garcia, J. Understanding user behavioral intention to adopt a search engine that promotes sustainable water management. Symmetry 2018, 10, 584. [CrossRef]

75. Palos-Sanchez, P.; Saura, J. The effect of internet searches on afforestation: The case of a green search engine. Forests 2018, 9, 51. [CrossRef]

76. Breuer, R.; Malte, B.; Andreas, E. Incorporating Long-term Effects in Determining the Effectiveness of Different Types of Online Advertising. Mark. Lett. 2011, 22, 327-340. [CrossRef]

77. Deighton, J.; Henderson, C.; Neslin, S.A. The Effects of Advertising on Brand Switching and Repeat Purchasing. J. Mark. Res. 1994, 31, 28-43. [CrossRef]

78. MacInnis, D.J.; Rao, A.; Weiss, A. Assessing When Increased Media Weight of Real-world Advertisements Helps Sales. J. Mark. Res. 2002, 39, 391-407. [CrossRef]

79. Ahmed, R.R.; Vveinhardt, J.; Štreimikienè, D.; Awais, M. Mediating and Marketing factors influence the prescription behavior of Physicians: An Empirical Investigation. Amfiteatru Econ. 2016, 18, 153-167.

80. Ahmed, R.R.; Vveinhardt, J.; Štreimikienè, D. The direct and indirect impact of Pharmaceutical industry in Economic expansion and Job creation: Evidence from Bootstrapping and Normal theory methods. Amfiteatru Econ. 2018, 20, 454-469. [CrossRef]

81. Bush, A.J.; Bush, V.; Harris, S. Advertiser perceptions of the Internet as a marketing communications tool. J. Advert. Res. 1998, 38, 17-27.

82. Danaher, P.J.; Mullarkey, G.W. Factors Affecting Online Advertising Recall: A Study of Students. J. Advert. Res. 2003, 43, 252-267. [CrossRef] 
83. Pabedinskaitè, A.; Fiodorovaitè, D. E-marketing for higher education institution. In Proceedings of the 10th International Conference Liberec Economic Forum, Liberec, Czech Republic, 19-20 September 2011; pp. 382-391.

84. Chatterjee, P.; Hoffman, D.L.; Novak, T.P. Modeling the Clickstream: Implications for Web-Based Advertising Efforts. Mark. Sci. 2003, 22, 520-541. [CrossRef]

85. Mangold, W.G.; Faulds, D.J. Social media: The new hybrid element of the promotion mix. Bus. Horiz. 2009, 52, 357-365. [CrossRef]

86. Vakratsas, D.; Ambler, T. How advertising works: What do we really know? J. Mark. 1999. [CrossRef]

87. Laroche, M.; Habibi, M.R.; Richard, M.O.; Sankaranarayanan, R. The effects of social media based brand communities on brand community markers, value creation practices, brand trust and brand loyalty. Comput. Hum. Behav. 2012, 28, 1755-1767. [CrossRef]

88. Blair, M.K. Using Digital and Social Media Platforms for Social Marketing; Oxford Medicine Online; Oxford University Press: Oxford, UK, 2017.

89. Dreze, X.; Hussherr, F.X. Internet advertising: Is anybody watching? J. Interact. Mark. 2003, 17, 8-23. [CrossRef]

90. Li, X.; Chan, K.W.; Kim, S. Service with Emoticons: How Customers Interpret Employee Use of Emoticons in Online Service Encounters. J. Consum. Res. 2019, 45, 973-987. [CrossRef]

91. Palos-Sanchez, P.; Saura, J.R.; Martin-Velicia, F. A study of the effects of programmatic advertising on users' concerns about privacy overtime. J. Bus. Res. 2019, 96, 61-72. [CrossRef]

92. Kim, K.; Stout, P.A.; Yoo, C.Y. Assessing the effects of animation in online banner advertising: Hierarchy of effects model. J. Interact. Advert. 2004, 4, 49-60.

93. Popp, B.; Woratschek, H. Consumer-brand identification revisited: An integrative framework of brand identification, customer satisfaction, and price image and their role for brand loyalty and word of mouth. J. Brand Manag. 2017, 24. [CrossRef]

94. McQuarrie, E.F.; Mick, D.G. Visual Rhetoric in Advertising: Text Interpretive, Experimental, and Reader-Response Analyses. J. Consum. Res. 1999, 26, 37-54. [CrossRef]

95. McCoy, S.; Everard, A.; Polak, P.; Galletta, D.F. The effects of online advertising. Commun. ACM 2007, 50, 84-88. [CrossRef]

96. Bevan, B. Northern Exposure: Interpretative Devolution and the Iron Ages in Britain; University of Leicester: Leicester, UK, 1999; pp. 1-19.

97. Noyes, J.; Baber, C. User-Centered Design of Systems; Springer: Berlin/Heidelberg, Germany, 1999.

98. Pieters, R.; Wedel, M. Attention Capture and Transfer in Advertising: Brand, Pictoral and Text-Size Effects. J. Mark. 2004, 68, 36-50. [CrossRef]

99. Xie, T.F.; Donthu, N.; Lohtia, R.; Osmonbekov, T. Emotional Appeal and Incentive Offering in Banner Advertisements. J. Interact. Advert. 2004, 4, 30-37. [CrossRef]

100. Maureen, H.; Grey, A. Getting Something for Nothing: The Impact of a Sample Offer and User Mode on Banner Ad Response. J. Interact. Advert. 2005, 6, 105-117.

101. Gentile, C.; Spiller, N.; Noci, C. How to sustain the customer experience: An overview of experience components that co-create value with the customer. Eur. Manag. J. 2007, 25, 395-410. [CrossRef]

102. Schiffman, L.; Wisenblit, J. Consumer Behavior, 11th ed.; Pearson Education: Harlow, UK, 2015.

103. Yoon, S.J. The antecedents and consequences of trust in online purchase decisions. J. Interact. Mark. 2002, 16, 47-63. [CrossRef]

104. Gallagher, K.; Foster, K.D.; Parsons, J. The medium is not the message: Advertising effectiveness and content evaluation in print and on the web. J. Advert. Res. 2001,41,57-70. [CrossRef]

105. Bennett, R.; Rundle-Thiele, S. Measuring attitudinal brand loyalty. J. Brand Manag. 2002, 3, $193-209$. [CrossRef]

106. Chaudhuri, A.; Holbrook, M.B. The chain of effects from brand trusts and brand affect to brand performance: The role of brand loyalty. J. Mark. 2001, 65, 81-93. [CrossRef]

107. Oliver, R.L. Whence customer loyalty. J. Mark. 1999, 63, 33-44. [CrossRef]

108. Keller, K.L. Conceptualizing, measuring and managing customer based brand equity. J. Mark. 1993, 57, 1-22. [CrossRef]

109. Aaker, D.A. Managing Brand Equity; Free Press: New York, NY, USA, 1991; pp. 19-32. 
110. Kapferer, J.N. Strategic Brand Management: Creating and Sustaining Brand Equity Long Term, 2nd ed.; Kogan Page: London, UK, 1997.

111. Frambach, R.T.; Roest, H.C.A.; Krishnan, T.V. The impact of consumer Internet experience on channel preference and usage intentions across the different stages of the buying process. J. Interact. Mark. 2007, 21, 26-41. [CrossRef]

112. Brito, A. Organizational Culture. J. Mark. 2011, 54, 14-21.

113. Brakus, J.J.; Schmitt, B.H.; Zarantonello, L. Brand Experience: What Is It? How Is It Measured? Does It Affect Loyalty? J. Mark. 2009, 73, 52-68. [CrossRef]

114. Mascarenhas, O.A.; Kesavan, R.; Bernacchi, M. Lasting customer loyalty: A total customer experience approach. J. Consum. Mark. 2006, 23, 387-405. [CrossRef]

115. Court, D.; Elzinga, D.; Mulder, S.; Vetvik, O.J. The consumer decision journey. Mckinsey Q. 2009, 3, 1-11.

116. Cox, S.A. Online Social Network Member Attitude toward Online Advertising Formats. Master's Thesis, The Rochester Institute of Technology, Rochester, NY, USA, 2010.

117. O'Malley, L.; Tynan, C. Relationship marketing in consumer markets-Rhetoric or reality? Eur. J. Mark. 2000, 34, 797-815. [CrossRef]

118. Richins, M.L. 16-Consumption Emotions, in Product Experience; Schifferstein, H.N.J., Hekkert, P., Eds.; Elsevier: San Diego, CA, USA, 2008; pp. 399-422.

119. Mugge, R.; Schifferstein, H.N.J.; Schoormans, J.P.L. Product attachment and satisfaction: Understanding consumers' post purchase behavior. J. Consum. Mark. 2010, 27, 271-282. [CrossRef]

120. Chu, W.; Song, M.R.; Choi, B. Post-purchase disadvantages of a less preferred brand and how they can be overcome: An examination of regret and attribution. J. Appl. Soc. Psychol. 2013, 43, 887-898. [CrossRef]

121. Leigh, J.H.; Gabel, T.G. Symbolic Interactionism: Its Effects on Consumer Behavior and Implications for Marketing Strategy. J. Consum. Mark. 1992, 9, 27-38. [CrossRef]

122. Groeger, L.; Buttle, F. Deciphering Word-of-Mouth Marketing Campaign Reach: Everyday Conversation Versus Institutionalized Word of Mouth. J. Advert. Res. 2016, 56, 368-384. [CrossRef]

123. Murtiasih, S.; Sucherly; Siringoringo, H. How word of mouth influence brand equity for automotive products in Indonesia. Procedia Soc. Behav. Sci. 2013, 81, 40-44. [CrossRef]

124. Herr, P.M.; Kardes, F.R.; Kim, J. Effects of word-of-mouth and product-attribute information on persuasion: An accessibility-diagnosticity perspective. J. Consum. Res. 1991, 17, 454-462. [CrossRef]

125. Virvilaite, R.; Tumasonyte, D.; Sliburyte, L. The influence of word of mouth communication on brand equity: Receiver perspectives. Procedia Soc. Behav. Sci. 2015, 213, 641-646. [CrossRef]

126. Cornelissen, J. Corporate image: An audience centered model. Corp. Commun. Int. J. 2000, 5, 119-125. [CrossRef]

127. Vermeulen, I.E.; Seegers, D. Tried and tested: The impact of online hotel reviews on consumer consideration. Tour. Manag. J. 2009, 30, 123-127. [CrossRef]

128. Morgan, N.J.; Pritchard, A.; Piggott, R. Destination branding and the role of the stakeholders: The case of New Zealand. J. Vacat. Mark. 2003, 9, 285-299. [CrossRef]

129. Goldenberg, J.; Libai, B.; Muller, E. Talk of the network: A complex systems look at the underlying process of word-of-mouth. J. Mark. Lett. 2001, 12, 211-223. [CrossRef]

130. Sanchez-Franco, M.J.; Ramos, A.F.V.; Velicia, F.A.M. The moderating effect of gender on relationship quality and loyalty toward Internet service providers. Inf. Manag. 2009, 46, 196-202. [CrossRef]

131. Ahuja, V. Development of an optimal solution for digital marketing variables in an online tool. Int. J. Internet Mark. Advert. 2015, 9, 49-65. [CrossRef]

132. Colrain, M.; Zuppo, M. Defining ICT in a Boundaryless World: The Development of a Working Hierarchy. Int. J. Manag. Inf. Technol. 2012, 4. [CrossRef]

133. Ziden, A.A.; Ismail, I.; Spian, R.; Kumutha, K. The effects of ICT use in teaching and learning on students' achievement in science subject in a primary school in Malaysia. Malays. J. Distance Educ. 2011, 13, $19-32$.

134. Chandler, D.; Munday, R. Information Technology, a Dictionary of Media and Communication, 1st ed.; Oxford University Press: Oxford, UK, 2012.

135. Montgomery, K.C.; Chester, J. Interactive Food and Beverage Marketing: Targeting Adolescents in the Digital Age. J. Adolesc. Health 2009, 45, S18-S29. [CrossRef]

136. Chaffey, D. E-Business and E-Commerce Management, 3rd ed.; Prentice Hall: Alexandria, VA, USA, 2008. 
137. Chi, H. Interactive Digital Advertising vs. Virtual Brand Community: Exploratory Study of User Motivation and Social Media Marketing Responses in Taiwan. J. Interact. Advert. 2011, 12, 44-61. [CrossRef]

138. Munsell, C.R.; Harris, J.L.; Sarda, V.; Schwartz, M.B. Parents' beliefs about the healthfulness of sugary drink options: Opportunities to address misperceptions. Public Health Nutr. 2015, 19, 46-54. [CrossRef] [PubMed]

139. Holzer, A.; Ondrus, J. Trends in mobile application development. In Lecture Notes of the Institute for Computer Sciences, Social Informatics and Telecommunications Engineering; Springer: Berlin/Heidelberg, Germany, 2009; pp. 55-64.

140. Lulu, D.L.B.; Kuflik, T. Wise Mobile Icons Organization: Apps Taxonomy Classification Using Functionality Mining to Ease Apps Finding. Mob. Inf. Syst. 2016, 2016, 3083450.

141. Jobe, W. Native Apps vs. Mobile Web Apps. Int. J. Interact. Mob. Technol. 2013, 7, 27. [CrossRef]

142. Bu, N.; Niu, S.; Yu, L.; Ma, W.; Long, G. Bridging Semantic Gap between App Names: Collective Matrix Factorization for Similar Mobile App Recommendation. In Lecture Notes in Computer Science; Springer: Berlin/Heidelberg, Germany, 2016; pp. 324-339.

143. Mady, T.T. Sentiment toward marketing: Should we care about consumer alienation and readiness to use technology? J. Consum. Behav. 2011, 10, 192-204. [CrossRef]

144. Anderson, J.C.; Gerbing, D.W. Structural equation modeling in practice: A review and recommended two-step approach. Psychol. Bull. 1988, 103, 411-423. [CrossRef]

145. Huang, J.H.; Lee, B.C.Y.; Ho, S.H. Consumer attitude toward grey market goods. Int. Mark. Rev. 2004, 21, 598-614. [CrossRef]

146. Rutherford, G.S.W.; Hair, J.F.; Anderson, R.E.; Tatham, R.L. Multivariate data analysis. Statistician 1988, 37, 484. [CrossRef]

147. Byrne, B.M. Structural Equation Modeling with AMOS, Basic Concepts, Application and Programming, 2nd ed.; Lawrence Erlbaum Associates: Mahwah, NJ, USA, 2009.

148. Leech, N.L.; Barrett, K.C.; Morgan, G.A. SPSS for Intermediate Statistics: Use and Interpretation, 4th ed.; Lawrence Erlbaum Association, Inc.: Mahwah, NJ, USA, 2011.

149. Bartlett, M.S. A note on the multiplying factors for various $\mathrm{x}^{2}$ approximations. J. R. Stat. Soc. Ser. B 1954, 16, 296-298.

150. Kaiser, H.F. An index of factorial simplicity. Psychometrika 1974, 39, 31-36. [CrossRef]

151. Fornell, C.; Larcker, D.F. Evaluating structural equation models with unobservable variables and measurement error. J. Mark. Res. 1981, 18, 39-50. [CrossRef]

152. Hsieh, Y.C.; Hiang, S.T. A Study of the Impacts of Service Quality on Relationship Quality in Search-Experience-Credence Services. Total Qual. Manag. 2004, 15, 43-58. [CrossRef]

153. Kline, R.B. Principles and Practice of Structural Equation Modeling, 3rd ed.; Guilford Press: New York, NY, USA, 2010.

154. Hooper, D.; Coughlan, J.; Mullen, M.R. Structural equation modelling: Guidelines for determining model fit. J. Bus. Res. Methods 2008, 6, 53-60.

155. Balakrishnan, N.; Barmalzan, G.; Haidari, A. Multivariate stochastic comparisons of multivariate mixture models and their applications. J. Multivar. Anal. 2016, 145, 37-43. [CrossRef]

156. Meyers, L.S.; Gamst, G.; Guarino, A. Applied Multivariate Research: Design and Interpretation; Sage Publications, Inc.: Thousand Oaks, CA, USA, 2006.

157. Hayes, A.F. Introduction to Mediation, Moderation, and Conditional Process Analysis. A Regression-Based Approach; The Guilford Press: New York, NY, USA, 2013.

(C) 2019 by the authors. Licensee MDPI, Basel, Switzerland. This article is an open access article distributed under the terms and conditions of the Creative Commons Attribution (CC BY) license (http://creativecommons.org/licenses/by/4.0/). 